\title{
ENERGY USE IN NEW ZEALAND
}

\author{
AGRICULTURAL PRODUCTION
}

\author{
P.D. Chudleigh \\ Glen Greer
}

\begin{abstract}
Views expressed in Agricultural Economics Research Unit Discussion Papers are those of the author(s) and do not necessarily reflect the views of the Director, other members of the staff, or members of the Policy or Advisory Committees.
\end{abstract}

DISCUSSION PAPER NO. 68

AGRICULTURAL ECONOMICS RESEARCH UNIT

LINCOLN COLLEGE

CANTERBURY

NEW ZEALAND 


2. ESTIMATES OF ENERGY USE IN NEW ZEALAND AGRICULTURAL PRODUCTION

3. FUEL USE IN NEW ZEALAND AGRICULTURAL PRODUCTION

3.1 An Aggregate Time Series Analysis of Agricultural Fuel Use

3.2 Time Series Analysis of Fuel Use in the Sheep and Beef Sub-Sector

3.3 Data Deficiencies and Conclusions

4. FERTILISER USE IN NEW ZEALAND AGRICULTURAL PRODUCTION

4.1 An Aggregate Time Series Analysis of Fertiliser Use 15

4.2 Sub-Sectoral Analysis of Fertiliser Use 16

4.2.1 Sheep and Beef Sub-Sector 16

4.2.2 Dairy Sub-Sector 19

$\begin{array}{llr}4.3 & \text { Conclusion } & 19\end{array}$

5. IMPLICATIONS OF ENERGY PROBLEMS FOR NEW ZEALAND AGRICULTURAL PRODUCTION AND AGRICULTURAL POLICY

APPENDIX 1: Assumptions Used in the Formulation of Table 1

APPENDIX 2: Fertiliser and Fuel Subsidies, Rebates and Prices 

1. Energy Requirements of Inputs to New Zealand Farming $1971-1981$

2. Equations Derived for the Sheep and Beef Sub-Sector

\section{LIST OF FIGURES}

Page

1. Energy Use, Terms of Trade and Volume of Agricultura1 Production

2. Fuel Use per Hectare, Gross Output per Hectare and Real Fuel Price, Meat and Wool Sub-Sector 1960-1981

3. Fertiliser Usage, Fertiliser Price Index and Real Net Farm Income 1971-1981

4. Fertiliser Usage per Hectare, Fertiliser Price Index and Real Net Farm Income per Hectare: Meat and Wool Sub-Sector 1972-1981

5. Implied Fertiliser Usage per Hectare, Fertiliser Price Index and Real Net Farm Income per Hectare: Dairy Sub-Sector 1972-81 

PREFACE

This paper is an expanded version of a paper presented by the authors to the XV Pacific Science Congress held in Dunedin in February 1983.

Energy use in the production sector of New Zealand agriculture is of lesser significance than energy use in the servicing sectors, especially the transport sector. Nevertheless, given the sudden rise in energy prices over the past decade and the associated rising significance of the cost of energy inputs on the farm, it is important to assemble data on energy usage over time, and to identify factors affecting energy usage on the farm. These are the objectives of the present paper.

Other recent AERU publications associated with energy use in New Zealand agriculture include Research Report No.'s 80 and 128 and Discussion Paper No. 40. 

This paper reports estimates of the energy used in New Zealand agricultural production up to the farm gate during the decade 1972-1981. As well as a description of total energy usage, the paper shows how the most important energy intensive inputs, fuel and fertiliser, have varied in use over the period.

Analysis of aggregate fuel use data suggests that New Zealand farmers have not decreased fuel use over the period in response to increasing real fuel prices. The most likely explanation for this lies in the facts that fuel costs still constitute only a minor part of total farm costs; and fuel is not easily substituted for by other inputs.

On the other hand, fertiliser costs are responsible for a substantial proportion of total farm costs. Even so, fertiliser price is not the most important factor influencing fertiliser input levels. Farm Income appears the most important single factor influencing the varying level of fertiliser inputs from year to year.

Higher energy prices on the farm have been only one factor influencing New Zealand aggregate agricultural output over the past decade. The implications of higher energy prices for agriculture emanate from far wider sources than just farm production technologies and direct effects on farm production economies.

The success of conservation measures on changes in output or input mixes on New Zealand farms stemming from the higher energy prices have so far been mainly hypothetical or have not surfaced in available data. The lack of published data at the sub-sectoral level does not allow meaningful monitoring of changes that may be taking place. Also, disaggregation of data on energy use is important if interest is in estimating future energy inputs and how these may be affected by various agricultural policies. 



\section{INTRODUCTION}

Since the major increases in the real price of energy which occurred during the $1970 \mathrm{~s}$ there has been considerable effort expended around the world in assembling data describing energy inputs, flows, costs, outputs, ratios, efficiencies, and productivities associated with various agricultural sectors, production systems, and products. Hence, a good deal more is known today about energy use than was known a decade ago.

However, one may question the relevance of much of the effort. For example, farm gate energy ratios (energy output:input ratios) are not particularly useful since farm gate product prices reflect many characteristics other than energy content.

However, where agricultural products are destined for energy purposes alone (biomass for fuel) energy ratios can be important. Even in such a context farm gate energy ratios are less relevant than ratios calculated further along the product pipeline.

Aggregating the energy component of inputs in agricultural production systems to arrive at a total energy output can also be limiting in dealing with energy matters. The energy intensity and price per unit of energy vary amongst the forms in which the input of energy to farming is made, and substitution between forms is 1 imited. However, analysis based on the energy aggregate assumes a high degreee of substitution and price correlation and may also imply that blanket research, extension or policy instruments are possible within a total energy framework. In short it assumes that energy is homogeneous. In New Zealand, it is apparent that it is sensible to view energy as a set of resources differentiated as to form, whether imported or indigenous, renewable or non-renewable, and secure or insecure (e.g. Middle East oil).

On the other hand, energy productivities (i.e. product output per unit of energy input) can provide useful guidelines in assessing conservation and substitution technologies if energy costs continue to rise. Nevertheless, energy productivities need to be viewed alongside the productivities of other factors of agricultural production.

It is our view that it is important to establish a broad view of energy use in agricultural production, including trends and determinants of energy use. This is important in the New Zealand situation if energy supplies are considered to be insecure, to continue to increase in real prices in the future, to use scarce foreign exchange, or if energy use in agricultural production interacts with macro-economic or agricultural policy options. This broad view should first be taken at an aggregate energy level, notwithstanding the limitations of this approach already outlined. This procedure is adopted in the second section of this paper where aggregate estimates of energy used in New Zealand agricultural production over the past decade are presented. Trends are noted and the principal energy inputs of fuel and fertiliser identified.

Problems of disaggregating energy use (or even principal energy inputs) by farming sub-sector in New Zealand are severe. Attempts by the authors to reconcile totals of sub-sector estimates derived from 
farm survey data with aggregate agricultural sector estimates have not proved successful. Some idea of the relative intensities of energy use amongst the different sub-sectors has been obtained using a gross margin approach. The problems encountered and the conclusions reached are discussed in this second section.

The third section of the paper concentrates on fuel use in New Zealand agricultural production over the past decade. Determinants of annual fuel use are analysed at both aggregate and sub-sector level.

The fourth section of the paper investigates in a similar manner the second largest energy input to New Zealand agriculture, fertiliser.

Section 5 concludes the paper with some general discussion regarding the implications of energy problems for New Zealand agricultural production and agricultural policy. 


\section{ESTIMATES OF ENERGY USE IN NEW ZEALAND AGRICULTURAL PRODUCTION}

The first study of aggregate energy use in New Zealand agriculture was carried out by Brown and Pearson (1977) and referred to the period $1971 / 72$ to $1975 / 76$. Using process analysis (defining quantities of inputs to farming and assigning an energy value to each input), Brown and Pearson estimated that the direct energy inputs of fuel and electricity made up $9365 \mathrm{TJ}$ or 41.5 per cent of the total energy requirement of inputs to New Zealand farming over the $1971-76$ period. The remainder (13225 TJ or 58.5 per cent) comprised indirect energy inputs, dominated by fertiliser, tractors, and farm machinery. Using the same methodology and data sources, Johnson and Topp (1981) extended the analysis from $1976 / 77$ to $1979 / 80$.

The present authors have extended the analysis for a further year (1980/81), adjusted the earlier two sets of data for some minor discrepancies, and amalgamated all estimates into one table (Table 1). The assumptions made and data sources used in constructing Table 1 are as given in the two earlier studies and are detailed in Appendix 1. A number of features are worthy of comment:

(i) Total energy inputs to farming have not varied greatly over the decade. They range from $24760 \mathrm{TJ}$ in $1973-74$ to $20271 \mathrm{TJ}$ in $1974-75$ (coefficient of variation - 6.48 per cent). While direct energy inputs appear constant, indirect energy inputs in the form of fertiliser and new tractors contributed most of the variation in total energy usage over the period.

However, because the energy intensity of the various forms of energy input has been assumed constant over the period, increasing energy productivities in manufacturing or extraction would not be reflected in the indirect energy requirements in Table 1.

(ii) Information on annual input quantities was not satisfactory in some cases (e.g. other machinery, pesticides). This meant that variation and trends in such inputs are not reflected in the estimates.

(iii) The direct energy in liquid fuels and the indirect energy in fertiliser contributed 36 and 28 per cent respectively of the total energy requirement of inputs to New Zealand farming.

It might be expected that fluctuations in annual energy use would be a likely consequence of changes in the terms of trade which would encourage farmers to alter levels of production. Simple regression analysis showed that although energy use and the farmgate terms of trade have a moderate correlation $(r=.56)$, the extent to which the variation in energy use can be explained by changes in the terms of

Fertiliser contributed 80 per cent and new tractors 13 per cent of that part of the variance of total energy requirements associated with direct first order effects. 
TABLE !

Energy Requirements of Inputs to New Zeal and Farming

1971 - 1981 (TJ)

\begin{tabular}{|c|c|c|c|c|c|c|c|c|c|c|c|c|}
\hline & $1971-72$ & $1972-73$ & $1973-74$ & $1974-75$ & $1975-76$ & $1976-77$ & $1977-78$ & $1978-79$ & $1979--80$ & $|980-8|$ & $1971-1981$ & $\%$ \\
\hline Direct Energy Inputs & & & & & & & & . & & & & \\
\hline Motor Spirit/Diesel & 7985 & 8280 & 8145 & 7955 & 7790 & 7901 & 8189 & 8195 & 8118 & 7946 & 8050 & 35.8 \\
\hline Electricity & 1260 & 1346 & 1303 & 1332 & 1422 & 1476 & 1570 & 1458 & 1467 & 1645 & 1428 & 6.5 \\
\hline Total Direct & 9245 & 9626 & 9448 & 9287 & 9212 & 9377 & 9759 & 9653 & 9585 & 9591 & 9478 & 42.2 \\
\hline \multicolumn{13}{|l|}{ Indirect Energy Inputs } \\
\hline Fertiliser & 5451 & 7413 & 7923 & 4926 & 5861 & 5383 & 6731 & 7220 & 7157 & 5970 & 6404 & 28.5 \\
\hline Limestone & 131 & 151 & 150 & 142 & 149 & 160 & 156 & 160 & 149 & 159 & 151 & 0.7 \\
\hline Fert/Lime Transport & 461 & 560 & 564 & 432 & 504 & 399 & 417 & 429 & 422 & 375 & 456 & 2.0 \\
\hline $\begin{array}{l}\text { Ground contract } \\
\text { application }\end{array}$ & 289 & 353 & 357 & 266 & 314 & 321 & $33 \underset{4}{ }$ & 341 & 336 & 303 & 321 & 1.4 \\
\hline Ag. aerial operations & 397 & 526 & 569 & 399 & 424 & 470 & 497 & 472 & 482 & 413 & +465 & 2.1 \\
\hline New tractors & 1544 & 1876 & 1906 & 1309 & 1121 & 1062 & 811 & 997 & 852 & 844 & 1232 & 5.5 \\
\hline Other machinery & 2100 & 2100 & 2100 & 2100 & 2100 & 2100 & 2100 & 2100 & 2100 & 2100 & 2100 & 9.4 \\
\hline Fencing Posts & 297 & 297 & 297 & 297 & 297 & 335 & 335 & 335 & 335 & 335 & 316 & 1.4 \\
\hline Wire & 288 & 378 & 434 & 278 & 236 & 415 & 367 & 532 & 387 & 422 & 354 & 1.6 \\
\hline Drench and Dip & 18 & 18 & 18 & 18 & 18 & 18 & 18 & 18 & 18 & 18 & 18 & 0.1 \\
\hline Pesticides etc. & 327 & 819 & 544 & 367 & 571 & 748 & 748 & 748 & 748 & 748 & 637 & 2.8 \\
\hline Commercial Transport & 450 & 450 & 450 & 450 & 450 & 600 & 600 & 600 & 600 & 600 & 525 & 2.3 \\
\hline Total Indirect & 11753 & 14941 & 15312 & 10984 & 12045 & 12011 & 13114 & 13752 & 13586 & 12287 & 12979 & 57.8 \\
\hline TOTAL ENERGY & 20998 & 24567 & 24760 & 20271 & 21257 & 21388 & 22873 & 23405 & 23171 & 21878 & 22457 & 100.0 \\
\hline
\end{tabular}

Sources: 1971-72 to 1975-76: Adapted from Brown and Pearson (1977)

1975-76 to 1979-80: Adapted from Johnson and Topp (1981)

1980-81: Compiled by authors

Assumptions required are detailed in Appendix 1. 
trade or in total production is not significant at the 95 per cent level. Energy usage, the terms of trade index, and the volume index of agricultural production are shown in $F$ igure 1 . It can be seen that a marked decrease in total energy use occurred during the year ended 30 June 1981 while agricultural production increased. Reduced fertiliser use accounted for almost all the decline in energy use during that year and although it is likely that an output reduction will occur in the future as a consequence of lower soil fertility, particularly if fertiliser application is cut back in subsequent years, output would not be immediately affected. It was originally intended to apportion agricultural fuel and fertiliser use amongst sub-sectors of the farming sector using data obtained from continuous farm surveys and from the aggregate fuel and fertiliser delivery statistics compiled by the Department of Statistics and the Ministry of Agriculture and Fisheries respectively.

Continuous farm surveys presently conducted include: Annual Survey of Sheep and Beef Farms: New Zealand Meat and Wool Boards' Economic Service, Wellington.

An Economic Survey of Factory Supply Dairy Farms in New Zealand: New Zealand Dairy Board, Wellington.

An Economic Survey of New Zealand Town Milk Producers: Agricultural Economics Research Unit, Lincoln College.

An Economic Survey of New Zealand Wheat Growers: Agricultural Economics Research Unit, Lincoln College.

One problem is that these surveys do not cover the entire sector, omitting poultry, pig and maize growers as well as the rapidly growing horticultural sub-sector. Another problem lies in the weakness inherent in the data which are available.

Estimates have been made (Chudleigh, 1981; Brook, 1981, pers. comm.) of the proportion of the expenditure item 'Vehicles, fuel and power' attributable to fuel alone in the Meat and Wool Boards' Economic Service (MWBES) survey data. Comparison of the total fuel use in the meat and wool sector (obtained by aggregating up from 'all class average' data) with total fuel sold to farmers suggests that 80 per cent of all farm fuel used in 1980/81 was used by the meat and wool sector. This figure appears exceptionally high given that the area estimated by the MWBES to be covered by the population of farms from which their sample is drawn (number of farms multiplied by 'all class average' area) is only 55 per cent of the area of occupied farmland in New Zealand. Reasons for this discrepancy include the weakness associated with the "Deliveries to Agriculture' statistic as a proxy for total farm fuel use (discussed in Section 3 of the paper) and the difficulties involved in the estimation of exact farm numbers by which MWBES 'all class average' data should be multiplied.

It is unlikely that this form of analysis can be extended further. Neither the Dairy Board (Boyer, 1982 pers. comm.) nor the AERU (Moffitt, 1982 pers. comm.) are able to determine the proportion of 'Vehicle Expenses' attributable to fuel on survey farms. Although 'fuel and oil' is isolated as a separate expenditure item in the wheat Growers' Survey the fuel proportion has not been determined (Lough, 1982 pers. comm.).

It is possible, however, to determine the proportion of total fertiliser used by the sheep and beef and dairy sub-sectors. The total 
FIGURE 1

Energy Use, Terms of Trade and Volume of Agricultural Production

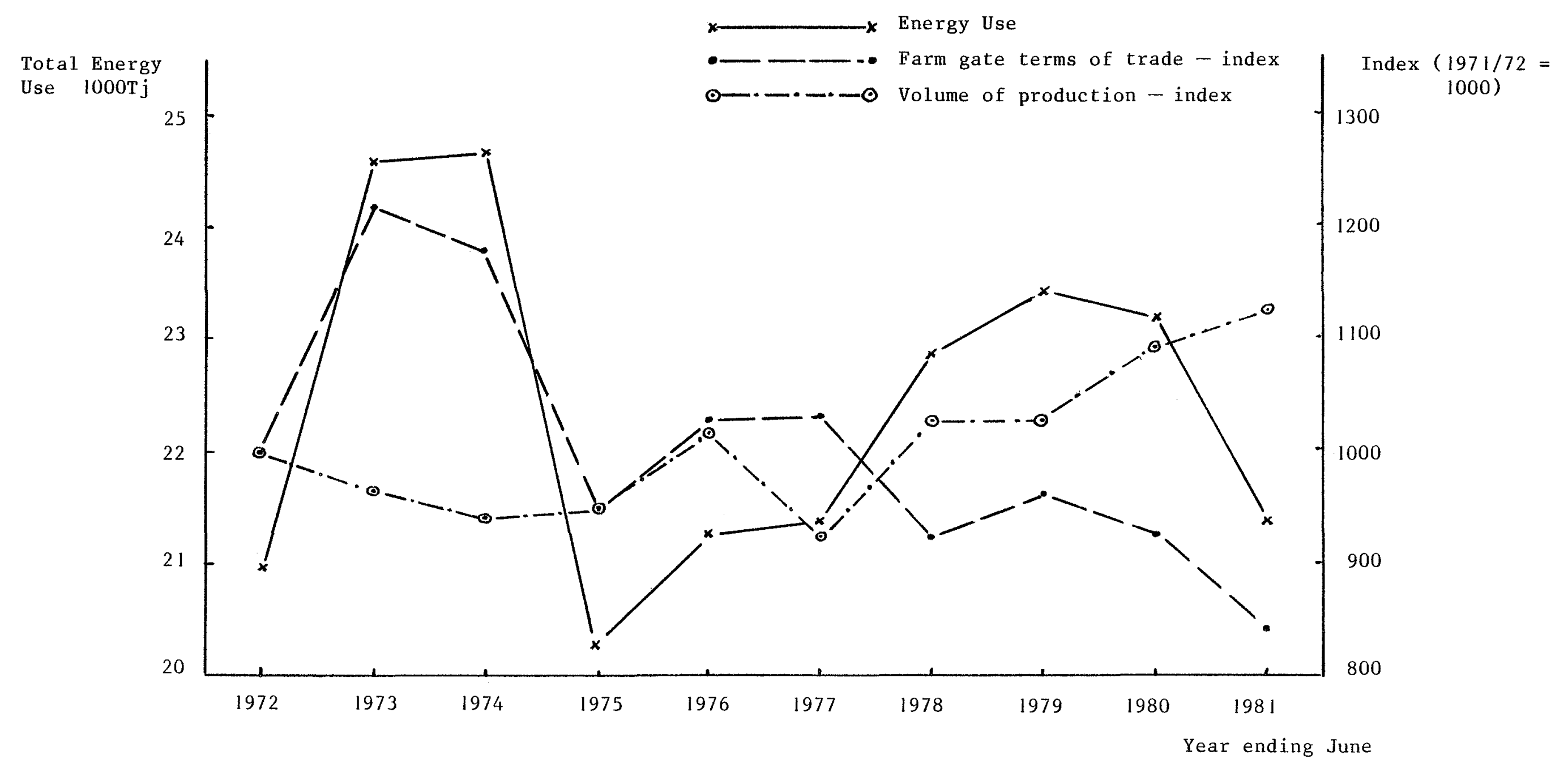


weight of fertiliser spread on grassland is published annually in the 'Agricultural Statistics' produced by the Department of Statistics. When this figure is compared with total fertiliser deliveries (Ministry of Agriculture and Fisheries, New Zealand Fertiliser Statistics, 1981) it is apparent that a very large proportion ( 92.5 per cent) of all fertiliser spread is spread on pasture. Discrepancies between fertiliser delivered and fertiliser spread in any year may arise, but estimates based on these figures are reasonably accurate. These suggest that in $1979 / 8060$ per cent of total fertiliser was used by the sheep and beef sub-sector and a further 19 per cent by the dairy sub-sector although these proportions may be slightly higher if much of the fertiliser not spread on grassland is purchased by either sector. It is not possible to determine the shares of the other sub-sectors in this manner since the greater part of fertiliser spread on cropping or horticultural properties is not spread on grassland and, therefore, not reported in 'Agricultural Statistics'.

Examination of gross margins for a number of enterprises gives only a limited perspective on the relative fuel use per hectare on different types of farm. Gross margins for sheep, beef and dairy enterprises do not include fuel costs since these are not regarded as direct costs. It is not therefore possible to make comparisons between livestock and cropping enterprises using this approach. A further problem is that individual gross margins deal with a particular production situation which need not represent the national average.

Cereal crops in general are less fuel intensive than small seed crops, but a more significant difference can be observed between cereal and small seeds and perennial horticultural crops such as kiwifruit, pip, stone and berry fruits. Perennial crops are particularly fuelintensive during the establishment phase. It is also apparent that these horticultural crops require a greater input of fertiliser, particularly nitrogenous fertilisers of high energy value, and of pesticides than do most field crops. ${ }^{2}$

It is therefore possible that large-scale increases in areas of horticultural crops will result in a higher energy demand by the sector. However, although areas of horticultural crops (excluding process crops and potatoes) have doubled since 1975, there has been no visible impact on aggregate agricultural energy use as yet since total areas of such crops are still less than half one per cent of occupied 1 and. Thus, major land use changes will be necessary before the impacts of higher energy demand by the horticultural sub-sector greatly influence the aggregate picture.

It must also be remembered that for economic efficiency any factor of production should be allocated where it can earn the highest return. McChesney et.al. (1982) have shown that the energy required per dollar of output produced by the kiwifruit industry is very much lower than for the dairy products and maize it has replaced. 

Fuel makes up only a small proportion of farm costs in New Zealand farming systems (see, for example, Chudleigh, Young and Brown, 1979) and tends to be used in essential farm activities in which it is not easily substituted for by other inputs. A study of fuel use on hill country farms (Lynch and Ward, 1981) reports substitution of motor bikes for landrovers as a practical possibility (and this has occurred to some extent since 1973). Most farmers considered substitution of horses for motor bikes was possible but that additional labour costs would more than offset potential savings in fuel costs.

It is likely therefore, that fuel use on New Zealand farms is not responsive to changes in its own price. In support of this non-responsiveness hypothesis, Partridge (1977) reported that Australian grazing farms cut back more on non-fuel inputs than on fuel inputs during the 1973-76 period when confronted with declining terms of trade.

Further evidence of this lack of price responsiveness was found by Thompson (1982) who carried out a normative linear programming study of the effects of fuel rationing and fuel price increases on a mixed cropping farm in the South Island. Thompson found that a simulated trebling of the 1978 farm fuel price resulted only in a 2 per cent cut in fuel used for productive purposes.

In a study on fuel use in the sheep/beef sub-sector of New Zealand agriculture over the period 1961 to 1977, Chudleigh (1982) found some evidence of a consumption response to changes in fuel price. Fuel use appeared also to be linked positively with output on sheep and beef farms. A complicating feature of the above study was that the data spanned an initial decade of increasing production and fuel use with decreasing real fuel prices (the 1960 's) followed by a decade of static production and increasing real fuel prices (the 1970's).

It was, therefore, decided to conduct an aggregate analysis of agricultural fuel use, and then to repeat Chudleigh's analysis using additional data from 1977 to 1981 and analysing the two decades separately.

\subsection{An Aggregate Time Series Analysis of Agricultural Fuel Use}

The basic hypothesis tested in the present study was that agricultural fuel use is a function of farm output and real fuel price.

Total fuel input data for the period 1971-72 to 1980-81 as presented in Table 1 was regressed against the volume index of agricultural production and the weighted net real price of fuel to the farmer. The weighted net real fuel price was constructed by calculating annual per litre prices for both diesel and petrol using a monthly weighting and combining these according to the estimated proportions of the two fuels delivered to farmers. (Chudleigh, 1982) to produce a single weighted net fuel price. (Details of the fuel price index are given in Appendix 2.) This was converted to real terms using the consumer price index. Rebates available to farmers were subtracted from fuel prices before these calculations were undertaken. 
No significant relationship could be established, thus leading to the conclusion that aggregate fuel use over the period was not responsive to changes in fuel price. Because output did not change significantly over this period, it was not surprising to find fuel use and farm output were not 1 inked.

\subsection{Time Series Analysis of Fuel Use in the Sheep and. Beef Sub-Sector}

The same hypothesis as above was tested using MWBES survey data. Output and fuel use per hectare were substituted for the total output and fuel variables of the previous analysis to make comparison with Chudleigh's (1982) model easier. Output per hectare was estimated by deflating gross income per hectare by the Index of export meat, wool and by-product prices. Estimates of fuel inputs were derived using the estimates of fuel expenditure per hectare supplied by Chudleigh (1982) for the years 1961-77, and by the MWBES for the years 1978-1981. Expenditure was deflated by the weighted net fuel price to determine the implied physical fuel input. The fuel price variable calculated for the aggregate analysis was also used for the sub-sectoral analysis.

When an additional four years' data, spanning the period 1978-1981, were added to the data used by Chudleigh and the same regression tested the significance of the relationship was markedly reduced, and problems of autocorrelation were encountered. When the model was fitted to the data for the years of interest to the present study (1972-81) neither price nor output variable appeared signficant, further refuting the price responsiveness hypothesis. In order to clarify the situation regarding the $1960^{\prime} \mathrm{s}$, data for the period 1960 to 1971 were fitted to the same model and a highly significant relationship was obtained. The equations derived and their associated statistics are presented in Table 2, and the time series used are graphed in Figure 2.

TABLE 2

Equations Derived for the Sheep and Beef Sub-Sector

\begin{tabular}{|c|c|c|c|}
\hline Year & Equation & $\begin{array}{l}\text { Durbin } \\
\text { Watson }\end{array}$ & $\overline{\mathrm{R}}^{2}$ \\
\hline $1961-71$ & $\begin{aligned} \text { Fuel /ha }= & 19.3-1.40 \text { Price }+0.170 \text { Output } / \text { ha } \\
& (t=-11.129 * *)(t=3.032 *)\end{aligned}$ & 2.203 & 0.937 \\
\hline $1972-81$ & $\begin{aligned} \text { Fuel } / \mathrm{ha}= & 15.80-0.10 \text { Price }+0.04 \text { Output } / \text { ha } \\
& (t=-1.013)(t=0.500)\end{aligned}$ & 1.7949 & -0.118 \\
\hline $1961-81$ & $\begin{aligned} \text { Fuel /ha }= & 0.24-0.30 \text { Price }+0.21 \text { Output } / \text { ha } \\
& (t=-2.654 * *)(t=3.033 * *)\end{aligned}$ & 0.9354 & 0.298 \\
\hline
\end{tabular}

The relationship depicted by the first equation suggests that the sustained increase in fuel inputs in the $1960^{\prime}$ 's was related strongly to the decline in real fuel prices and less strongly to the growth in farm output. However, too much emphasis should not be placed on the apparent 
FIGURE 2

Fuel Use Per Hectare, Gross Output per Hectare and Real Fuel Price,

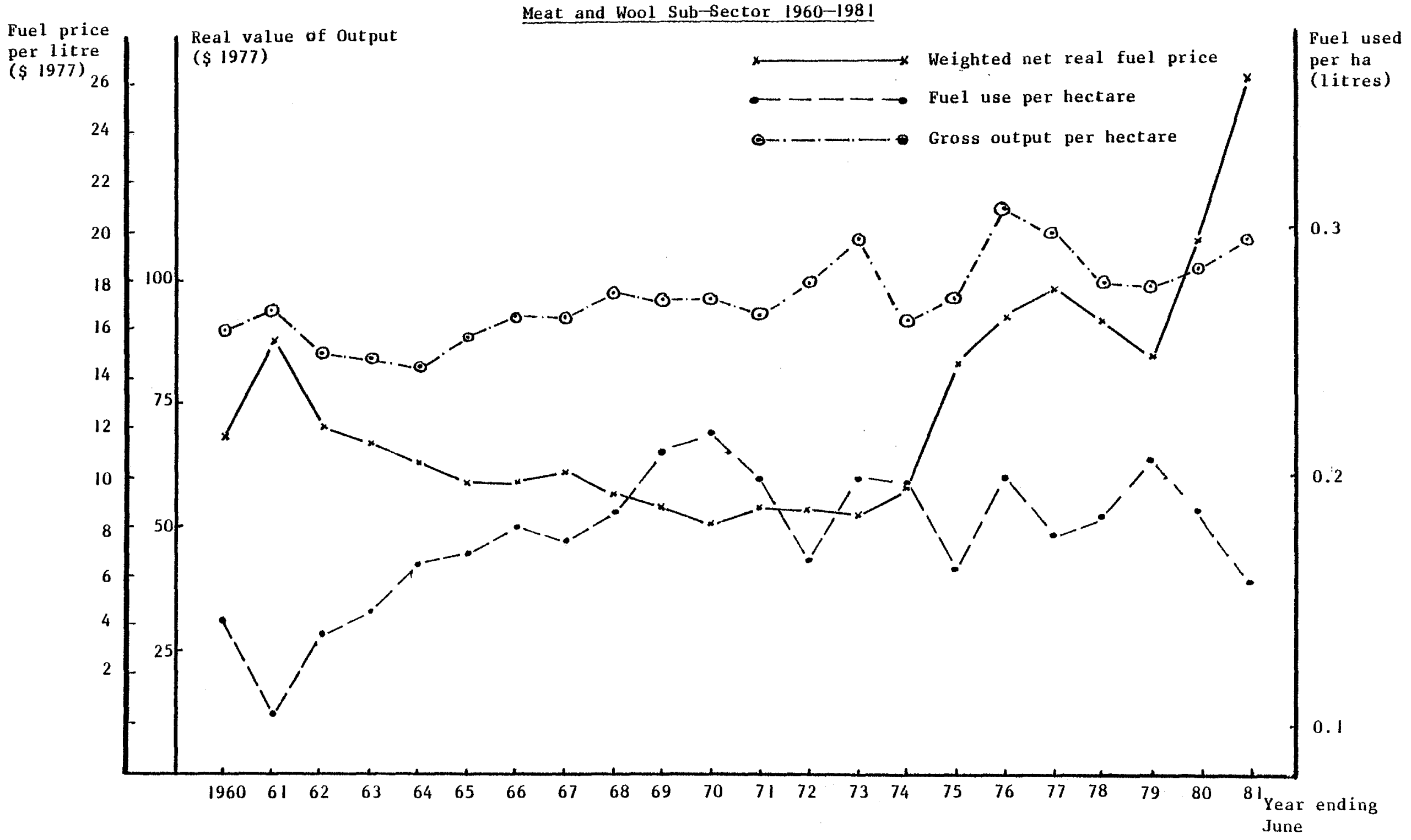


strength of the relationship between fuel use and real fuel price during the $1960^{\prime} \mathrm{s}$ as a number of other factors operating at the time must be considered. Fuel was one of a number of inputs whose real price fell during the 1960 's. At the same time large areas of cultivation-intensive (and therefore fuel-intensive) hill country development were being undertaken and mechanisation of farm practices was increasing. In addition, the use of cars on farms increased markedly during the period (McChesney, 1982, pers. comm.). The expansion of output in the later years of the decade may have been stimulated by the aggregate fall in the prices of inputs including fuel. To assume a high level of price responsiveness (Elasticity $=-1.033$ calculated for $1961-71$ ) during the period on the basis of a simple model would not be justified.

The contention that fuel inputs are determined in part by farm output remains tenable, despite the poor relationship demonstrated during the 1970's, since the lack of output variation during the period and the lack of precision in fuel use estimates has made any relationship difficult to establish.

\subsection{Data Deficiencies and Conclusions}

There are a number of weaknesses inherent in the data sources used which reduce the validity of any conclusions drawn from the current analysis. Briefly these include (McChesney, 1982, Pers. Comm.):

3.3.1 'Deliveries to Agriculture' may not include all fuel delivered to farmers holding accounts through third parties. Since fuel purchased by rural garages is usually attributed to agriculture and hunting some fuel used by other rural businesses will be included.

\subsubsection{Small but signficant quantities of diesel delivered to} farms are used for domestic heating.

3.3.3 The value of total fuel inputs used in this study is the proportion of 'Deliveries to Agriculture and Hunting' estimated by Johnson and Topp (1981) to have been delivered to farmers. This estimate has been used to exclude fuel used in off-farm transport etc. However, also excluded is fuel used by agricultural contractors involved in on-farm work which would otherwise by undertaken by the farmer. The problem would not be solved by substituting the total 'Deliveries to Agriculture' for the estimated proportion since fuel purchased by operators also involved in a non-farm work may then be classified as 'Agriculture and Hunting'.

3.3.4 Difficulties also exist with data from the Meat and Wool Boards' Economic Service. The most important of these is that fuel used by contractors is not included in the farm fuel expenditure reported. A less significant problem is that domestic fuel use is sometimes included with fuel used in farm operations.

Any element of price responsiveness during the 1970's may be disguised by two aspects not captured by the analysis. Firstly, in times when farm costs are rising more rapidly than farm incomes farmers tend to undertake harvesting and cultivation operations otherwise performed by contractors, thus increasing the fuel delivered to the farm without increasing total fuel used on the farm. Secondly, by including diesel and gasoline in the single variable 'fuel', changes in the relative 
proportions of these two fuels, as the difference in their price changes, will be partly hidden.

Fuel costs are still a small part of total farm costs and fuel use is not easily substituted for by other inputs. Analysis of the aggregate data available both for the whole farm sector and for the meat and wool sub-sector suggests that New Zealand farmers have not decreased fuel use in the 1970 's in response to increasing real fuel prices. Analysis could not be undertaken on data from the annual survey conducted by the New Zealand Dairy Board because fuel could not be isolated as an expenditure item. 

SECTION 4

FERTILISER USE IN NEW ZEALAND AGRICULTURAL PRODUCTION

Fertiliser is the second largest energy input into New Zealand agriculture. Because of phosphate deficient soils and a strong dependence on legumes for nitrogen fixation, phosphatic fertilisers dominate the New Zealand fertiliser mix.

Already noted is the significance of the annual variability associated with fertiliser energy input. An analysis of the factors associated with the variability of fertiliser tonnage therefore was pursued.

Relatively little has been published concerning the factors affecting the demand for fertiliser in New Zealand. The Ministry of Agriculture and $\mathrm{Fisheries} \mathrm{Economics} \mathrm{Division} \mathrm{believe} \mathrm{that} \mathrm{"aggregate} \mathrm{fertiliser} \mathrm{demand}$ is a function of aggregate farm income, applied cost and climatic conditions" (M.A.F. N.Z. Fertiliser Statistics, 1981). Johnson (1969) in a study of fertiliser use in Southland during the 1960's observed a sharp response to changes in fertiliser price with a less marked response to change in farm income. He also noted that changes in fertiliser use would be associated with development of pastoral land which may be measured most easily by increases in stock numbers. A model designed to predict fertiliser use on the East Coast of the North Island suggested that the demand for fertiliser is elastic with respect to income and inelastic with respect to price (Robertson and Rodgers, 1973). Petrey (1982) suggests that gross income may be the best indicator of farmer demand for fertiliser in the immediate future. Unpublished research on the demand for phosphatic fertilisers in Australia has also found the income effect to be of much greater importance than the price effect in explaining variation in demand (Gargett, 1982, pers. comm.).

\subsection{An Aggregate Time Series Analysis of Fertiliser Use}

It was hypothesised that fertiliser use would be a function of real income, real fertiliser price and of Government policies designed to increase production through land development and higher livestock numbers. Several formulations of the model were tried using different specifications of the income and policy variables. Real gross income was calculated as the gross value of agricultural products converted to real terms using the all farming costs price index. ${ }^{3}$ The agricultural proprietors' surplus funds, similarly converted to real terms was used as an estimate of real net income. A terms of trade variable, the ratio of farm output prices to farm input prices was also tested. The policy variable employed was calculated by combining the total value of authorisations made under the Land Development Encouragement Loan (L.D.E.L.) and Livestock Incentive Schemes (L.I.S.). A lagged policy variable was also calculated using the assumption that half the value of authorisations would be paid in the year in which they were made, and half in the following year. Both policy variables were reduced to real terms by using the all farming costs price index. An index of real fertiliser

3 The all farming costs price index was chosen to deflate income since the greater part of the purchasing power of that income is directed towards the commodities whose prices are included in that index. 
prices was constructed by taking the ratio of fertiliser prices to the prices of all other farm inputs. The index of fertiliser prices includes also the costs of 1 ime and seed as well as spreading charges. A more appropriate index of the applied cost of fertiliser only was not available. The relationship between the index used and an index of the applied cost of superphosphate only is depicted graphically in Appendix 2.4 .

The most satisfactory formulation tried included real net income as an explanatory variable but excluded real price and policy variables. The equation is shown below:

$$
\text { Fertiliser Use (tonnes) }=\begin{array}{rcc}
\overrightarrow{\mathrm{R}}^{2} & \begin{array}{c}
\text { Durbin } \\
\text { Watson }
\end{array} \\
\begin{aligned}
(t=309+2.044 \mathrm{RNI} \\
\left(t=3.7123^{*} *\right)
\end{aligned} & 0.63 & 1.91
\end{array}
$$

The independent variable real gross income also reached significance in some equations fitted; nevertheless its level of significance and explanatory power were generally lower than net farm income. Terms of trade was only just significant when included as an independent variable and provided low levels of variance explanation. Lagging of income variables by one year did not result in the estimation of significant relationships.

When real fertiliser price was included as an additional independent variable the estimated coefficients were negative, as expected, but were not significant in any equation.

Although the inclusion of a lagged policy variable appeared to improve the explanatory power of the overall relationship slightly, the $t$ value calculated for the estimated coefficient was not significant at the 20 per cent level and problems of autocorrelation occurred. The time series used in this model are graphed in Figure 3.

\subsection{Sub-Sectoral Analysis of Fertiliser Use}

The hypothesis tested at the aggregate level was also tested using data on fertiliser use obtained from the continuous farm surveys of the sheep and beef and dairy sub-sectors.

\subsubsection{Sheep and Beef Sub-Sector}

Total fertiliser use per hectare was calculated by dividing MWBES data on fertiliser use per farm (Brook, 1982, pers. comm.) by the number of effective hectares. The real price of fertiliser was calculated by the same method as in Section 4.1. Gross and net income per hectare were derived directly from MWBES survey data and were deflated using the sheep farming costs price index. Sheep farmers' terms of exchange (MWBES, 1982) were included as the terms of trade variable. The policy variables constructed for the aggregate analysis were also used in this analysis. The total value of loans made under the L.I.S. and L.D.E.L. schemes is included since published data does not permit the apportioning of total loans paid between the sheep and beef and dairy sub-sectors although authorisations under the L.I.S. scheme are published by sub-sector. 
FIGURE 3

Fertiliser Usage, Fertiliser Price Index and Real Net Farm Income 1971-81

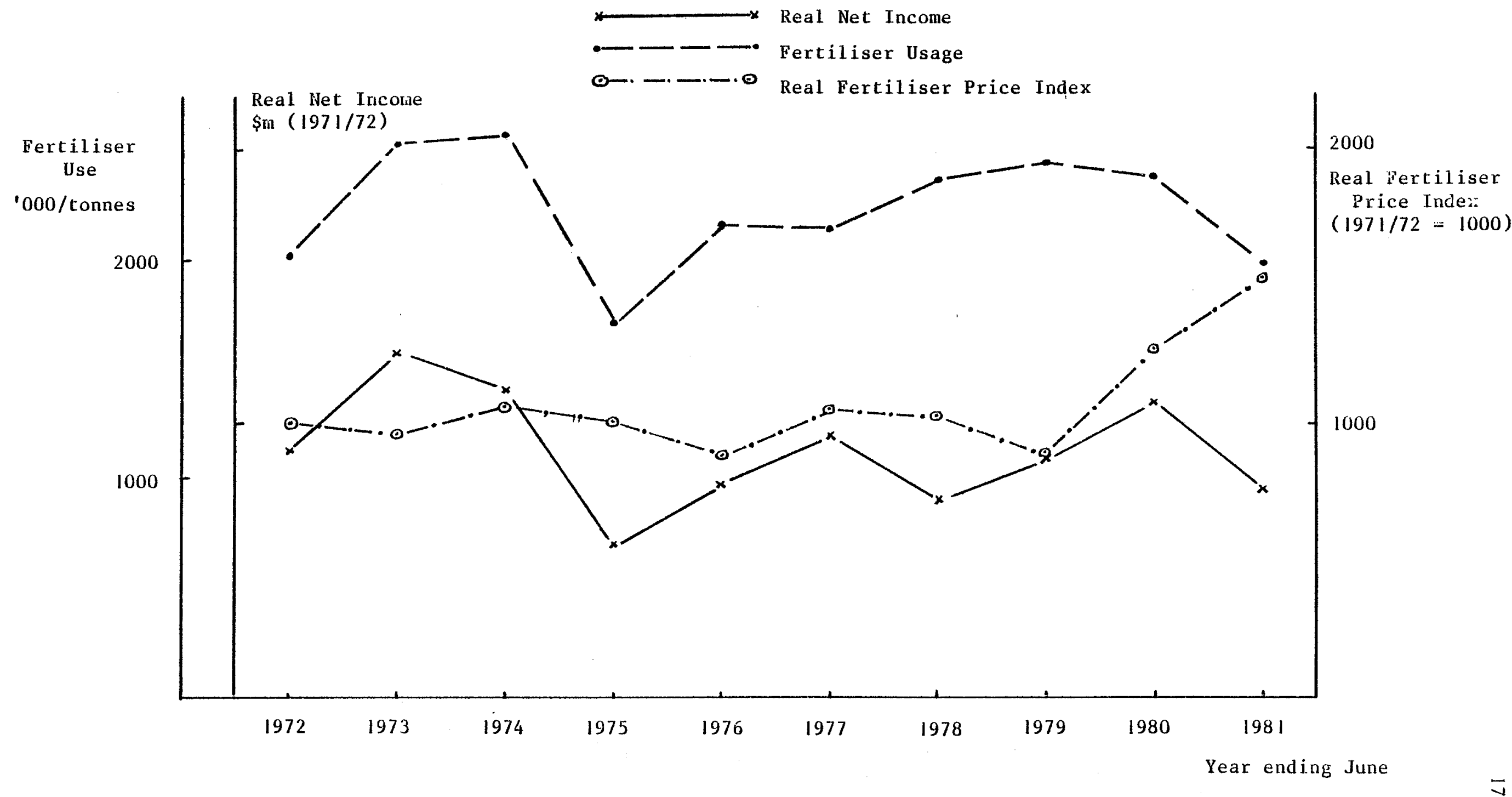


The derived equation which provides the greatest explanatory power is shown below and includes real gross income (RGI) as an explanatory variable. Neither net income nor fertiliser price were significant except in conjunction with the policy and lagged policy variables, when autocorrelation was also present. Terms of trade provided little explanatory power. The Durbin-Watson statistic shown below suggests that some measure of positive autocorrelation may be present but is not high enough to be conclusive. The time series used are depicted in Figure 4 .

$\begin{array}{rcc}\text { Fertiliser } / \text { ha }=39.95+1.521 \mathrm{RGI} & \overline{\mathrm{R}}^{2} & \text { Durbin Watson } \\ (t=4.651 * *) & 0.692 & 2.75\end{array}$

\subsubsection{Dairy Sub-Sector}

Data from the New Zealand Dairy Board's Annual Survey of Factory Supp1y Dairy Farms were used to repeat the analysis for the dairy sub-sector. Fertiliser use per hectare in this case was derived by deflating expenditure on fertiliser, 1 ime and seeds by the fertiliser and lime price index. Although seeds represent a comparatively small proportion of this expenditure, lime does not and its inclusion may reduce the validity of the exercise. Income data were derived from the survey and deflated by the dairy farming cost price index while fertiliser price (FP) and policy variables were the same as those used in the previous analyses. The two equations with most explanatory power are shown below.

$$
\begin{array}{rrr}
\text { Fertiliser } / \mathrm{ha}=18.772+\begin{array}{l}
0.044 \mathrm{NRI}-0.004 \mathrm{FP} \\
(t=2.41)(t=-3.31)
\end{array} & 0.774 & \begin{array}{r}
\text { Durban } \\
\text { Watson }
\end{array} \\
\text { Fertiliser } / \mathrm{ha}=18.700+\begin{array}{l}
0.024 \mathrm{RGI}-0.006 \mathrm{FP} \\
(t=1.76)(t=-4.84)
\end{array} & 0.713 & 1.665
\end{array}
$$

Both provide a moderately high level of explanation of the variation in fertiliser use, and both include real fertiliser price as an explanatory variable. The relationship between real net income (RNI) and fertiliser use appeared to be slightly stronger than the relationship between real gross income (RGI) and fertiliser use but it would be difficult to choose between the two given the deficiencies in the data. In the dairy sub-sector, the policy variable was strongly correlated with the net income variable $(r=-0.72)$ and its inclusion caused problems of autocorrelation and possibly of multicolinearity. The relationships including policy variables were discarded on these grounds. Real gross income/ha, fertiliser price and fertiliser used per hectare in the dairy-sector are shown in Figure 5.

\subsection{Conclusion}

Fertiliser costs make up a substantial proportion of farm expenditure in New Zealand pastoral farming systems. In 1980/81 the costs of fertiliser purchase, cartage and spreading made up 12 per cent of total cash expenditure on farms surveyed by the MWBES (Brook, 1982, pers. comm). 
Fertiliser Usage per Hectare, Fertiliser Price Index and Real Net Farm Income per Hectare: Meat and Wool Sub-Sector 1972-81

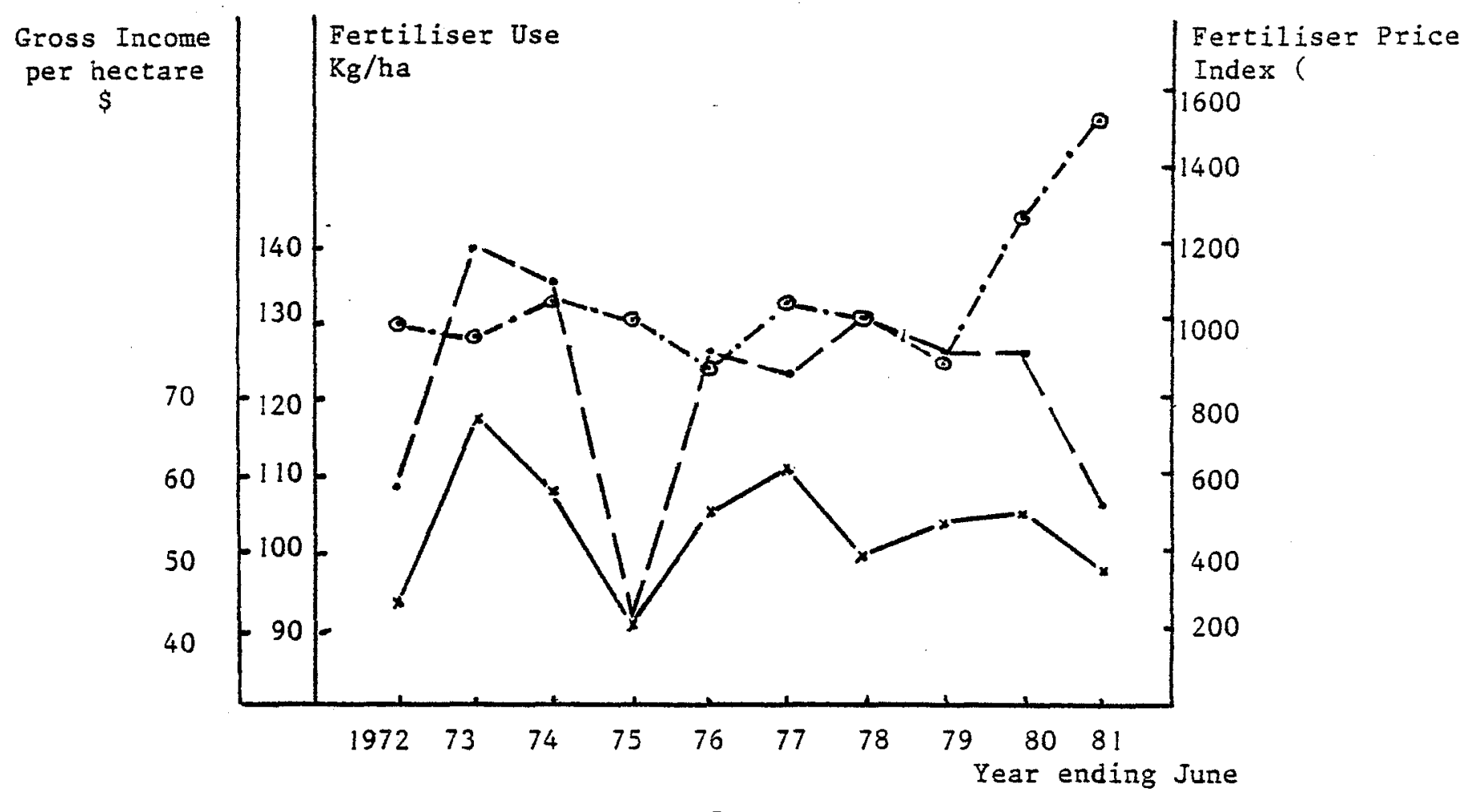

FIGURE 5

Implied Fertiliser Usage per Hectare, Fertiliser Price Index and

Real Net Farm Income per Hectare: Dairy Sub-Sector 1972-81

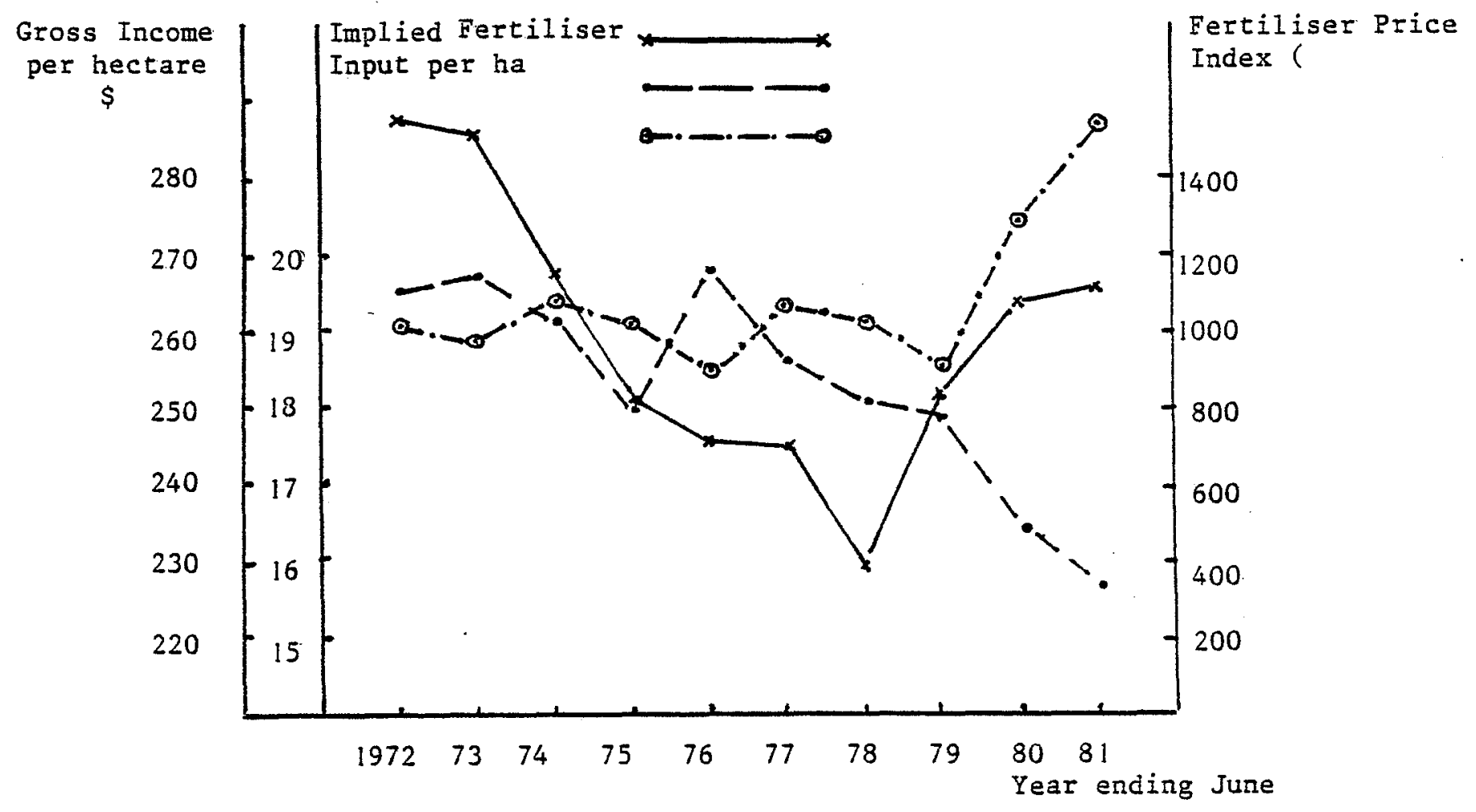


It would appear that fertiliser price is not the most important factor influencing fertiliser input levels although it appears to have been of greater significance in the dairy sub-sector than in the sheep and beef sub-sector. However, it is only since $1978 / 79$ that real fertiliser prices have begun to escalate. Before that time the fertiliser price subsidies prevailing were comparatively high in relation to the gross fertiliser price and farmers were not faced with price changes of great magnitude. If fertiliser prices continue to increase it is possible that the same analysis, repeated in five years' time would detect a greater degree of price responsiveness.

Income appears to have been the largest single factor influencing fertiliser inputs although on the basis of this analysis it is not possible to determine whether gross or net income is more important. In years of high income it appears that farmers 'bank' stores of fertiliser in the soil, thus avoiding paying tax and effectively carrying forward income in this form to future low income years. More complex analysis and more accurate data would be required to determine the exact effects of policies such as L.I.S. or L.D.E.L. on aggregate fertiliser use. 


\section{SECTION 5}

IMPLICATIONS OF ENERGY PROBLEMSS FOR NEW ZEALAND

AGRICULTURAL PRODUCTION AND AGRICULTURAL POLICY

Lockeretz (1977) has defined five categories of research into agricultural energy use. These include:

1. quantification of energy used in agriculture (for specific production processes as well as at aggregate levels)

2. economic impacts of energy problems on agricultural production.

3. comparative economic and energy costs of methods for producing a specific product

4. unconventional production methods using renewable or recycled energy sources

5. implications of the energy situation for agricultural policy.

So far only the first of these categories has been dealt with in this paper. In Section 2 an aggregate picture of energy use in New Zealand agricultural production has been presented. The aggregate estimates are associated with a number of data problems; nevertheless, the estimates give an indication of trends and relative importance of various energy inputs. Description of energy use by agricultural sub-sector poses difficulties.

The second category, the possible impacts of energy problems on New Zealand agricultural production, can be viewed as:

(i) Shortages of oil based fuels interfering with normal production practices and output

(ii) Decreased production due to higher energy prices

(iii) A change in the output mix due to changing relativities of input prices given constant technology

(iv) A change in the input mix due to changing relativities of input prices given constant technology

(v) Stimulation of the development and acceptance of new technologies and production systems as a consequence of higher energy prices.

Deliveries of fuel to agriculture and hunting made up approximately four per cent of total fuel deliveries in 1980-81 while agriculture's contribution to GDP was 10 per cent and an estimated 10.7 per cent of the labour force were employed in agriculture, fishing, forestry and hunting. Petroleum and petroleum products destined for agricultural use were responsible for less than one per cent of New Zealand's total import bill and fertiliser material imports accounted for a further 2.9 per cent. The agricultural sector generated approximately 71 per cent of New Zealand's foreign exchange earnings in that year. 
Because the agricultural producing sector accounts for only a small proportion of New Zealand oil based fuel consumption and a large proportion of export earnings, it is likely that the sector would be favoured in a serious shortage situation. However, this was not so with diesel restrictions in 1979/80, where farming, like other industries, was constrained in diesel purchases to quantities purchased in previous years.

In fact, should a serious fuel shortage occur, Thompson (1982) concluded that on a mixed cropping farm, physical rationing would be preferable to price induced rationing if farm incomes were not to be reduced significantly. To reduce fuel use by 19.5 per cent, for example, rationing may involve an income reduction of less than 4 per cent while a 1000 per cent price increase would be required to achieve the same fuel savings and would result in a net income reduction of nearly 33 per cent in the short run.

The evidence presented in this paper does not support the thesis that higher energy prices in the 1970's have reduced fuel consumption thereby reducing agricultural production. Many other factors have been operating on output including low overseas product prices relative to increasing energy and non-energy input costs faced by New Zealand farmers. Insofar as higher energy prices affect income, and contribute to a declining terms of trade, New Zealand aggregate agricultural production may be affected.

Perhaps a more important effect of higher energy prices on New Zealand agricultural production is via the energy influence on the transport sector. This has been dealt with elsewhere (Chudleigh et al., 1979; Copeland et al., 1982). Suffice it to say that the implications of higher energy prices for agriculture stem from far wider sources than from production technologies and production economics. For New Zealand agricultural production the two most important areas through which these implications arise are the effects on overseas shipping and the effects on the economies of countries in which New Zealand has traditionally sold food and fibre products at the luxury end of the range.

Changes in the New Zealand output mix have been shown to be related to relative product prices (Laing, 1982; Rich and Zwart, 1979), rather than to relative input prices. For example, beef/sheep, dairy/sheep, and wheat/sheep product substitutions have been identified as being largely due to relative product price effects. The substitution of kiwifruit for dairying is another output mix change due to product price relativities.

Output mix changes which are consequences of energy price increases are more evident in the cropping sub-sector than in the traditional pastoral sector. For example, Thompson (1982) showed that fuel price changes of 200 per cent would result in changes in the output mix on a Canterbury mixed cropping farm (substitution of one cereal for another) and it is possible that Southland wheat production could come under increasing cost pressures (due to high drying and transport costs in the future). The fact that some products are more transport-intensive than others may lead to a number of output mix changes as rising transportation costs adversely affect farmgate prices for those products. 
The most significant output mix change that may eventuate from continued energy price increases is that of biomass crops to produce alcohol fuels replacing pastoral and grain produce for human consumption. Dent (1979) estimated ex-factory costs of production of ethanol at 16-22 c/litre (1979\$) compared with an ex-refinery price of motor-spirit of $17 \mathrm{c} / 1$ itre or an imported price of motor spirit of $23 \mathrm{c} / 1$ itre. While recognising that the net impact on foreign exchange would depend on the produce displaced by the biomass (wheat or sheep products) and the import displaced by the ethanol (crude oil or motor spirit), Dent estimated the net impact on foreign exchange to be positive within the range of $\$ 540$ to $\$ 1,475$ per hectare of change. McLeod (1982) estimated ex-factory costs of production of ethanol (via fodder beet) at just over $30 \mathrm{c} / 1$ itre (in 1981\$) in the long term compared with $61 \mathrm{c} / 1$ itre (in 1981\$) in the initial years and an ex refinery price of motor spirit greater than $40 \mathrm{c} / 1$ itre in 1982.

The introduction of conservation practice on cropping farms which has occurred as fuel prices have increased is perhaps the most obvious example of input substitution and of the development and acceptance of new technologies and production systems. Increased use of herbicides and insecticides has been substituted for fuel-intensive cultivation practices. The change to all-grass wintering as a means of reducing fuel-intensive feed conservation practices such as haymaking is a further example of a change in production systems in response to increasing fuel costs.

Areas 2 and 3 of Lockeretz's classification cannot be dealt with in a purely economic framework since they involve technical development and evaluation of specific farming practices. They are not, therefore, addressed in the present context.

This paper is concluded therefore with some comments on his fifth area - implications of the energy situation for New Zealand agricultural policy. The focal point in such a discussion is the degree to which the market can be trusted to give correct price signals to producers regarding the appropriate allocation of resources to be used in pursuing New Zealand agricultural policy goals. If prices of imported energy have been artificially low in the past, it is only appropriate that agricultural production systems have been developed which take advantage of such input price relativities. When energy prices rise to "correct" levels, the market system encourages conservation, substitution by other inputs wherever possible, and research and development into new conservation and substitution technology. The policy question is whether such changes can occur without undermining the policy goal of increased agricultural production.

New Zealand agricultural production would appear to have absorbed the rapidly rising energy prices of the 1970 's but, in aggregate it does not appear that significant adjustments have been made. Two possible explanations for this are the low energy intensity of New Zealand's agricultural production and the inadequacy of the sub-sectoral data available. It has been estimated (Brown and Pearson, 1977) that the energy input to food production in New Zealand is one third of that which is required for equivalent production in the U.S.A. and little more than one quarter of the input required in the United Kingdom. Thus, it may be that there is little opportunity for New Zealand farmers to reduce their use of energy without affecting essential farming activities. 
Alternatively it may be that energy conservation measures have been successful in some sub-sectors of New Zealand agriculture and that these effects are disguised by increasing energy intensities elsewhere. The lack of published data at the sub-sectoral level does not permit examination of relative changes in energy intensity.

Disaggregation of data on energy use is of considerable importance if interest is in estimating future energy inputs and how these may be affected by various agricultural policies. If such planning exercises are to be undertaken it may be useful to assume that agricultural production is determined primarily by non-energy forces, and estimate how energy inputs into New Zealand agriculture will vary with production changes. If such a procedure is to be refined, disaggregating energy inputs by agricultural sub-sector would be a necessary task. In this respect it may be questionned whether New Zealand energy researchers have progressed as far as they should.

Tax and subsidy policies associated with principal energy inputs do not appear to have been distorting energy resource use. The subsidies, taxes and rebates on fertiliser and fuel are described in Appendix 2. Farm fuel use, like all number of liquid fuels is subject to a 15 per cent $t a x$ designed to protect domestic alternative fuels and encourage the efficient use of imported fuels. Since farm fuel use is not responsive to price changes it is unlikely that such a tax will reduce fuel use significantly.

Although fertiliser use is probably price inelastic, the elasticity is likely to be higher than fuel and encouragement of limited additional use at the margin could result from subsidisation. If the New Zealand fertiliser subsidy has existed to increase fertiliser use by lowering the price, it may not have been particularly successful. If it was introduced to compensate for higher costs faced by farmers due to differentially protected manufacturing and servicing sectors then it possibly just adds to the complex state of differential protection and compensation in New Zealand economic policies. 
Brown, W.A.N. and Pearson, R.G. (1977), The Energy Requirement of Farming in New Zealand, Research Report No. 80, Agricultural Economics Research Unit, Lincoln College.

Chudleigh, P.D. (1982), Fuel Use in New Zealand Agriculture: An Aggregate Time Series Analysis. Publication P.59, New Zealand Energy Research and Development Committee, University of Auckland.

Chudleigh, P.D., Young, S.L. and Brown, W.A.N. (1979), New Zealand Agriculture and Oil Price Increases. Discussion Paper No. 40, Agricultural Economics Research Unit, Lincoln College.

Copeland, M.C., Horsfield, A.K. and Chudleigh, P.D. (1982), Transport Energy in New Zealand's Overseas Trade, Report No. 80, New Zealand Energy Research and Development Committee, University of Auckland.

Dawson, S.M. (1982), Energy Requirements of Inputs to Agriculture in New Zealand - Occasional Paper No. 4, Joint Centre for Environmental Sciences - Lincoln College, Canterbury.

Dent, J.B.. (1979), Transport Energy from Crops. New Zealand Agricultural Science 13: 112-117.

Johnson, R.W.M. (1969) Fertiliser Use in Southland. Research Report No. 54, Agricultural Economics Research Unit, Lincoln College.

Johnson, R.W.M. and Topp, F.B. (1981), Use of Energy in New Zealand Agriculture 1976-1980. Discussion Paper 14/81, Economics Divison, Ministry of Agriculture and Fisheries, Wellington.

Laing, M.T. (1982), The New Zealand Pastoral Livestock Sector: An Econometric Model (Version 2). Research Report No. 127. Agricultural Economics Research Unit, Lincoln College.

Lockeretz, W. (1977), Agriculture and Energy. W. Lockeretz (ed). Academic Press, New York, p.734.

Lynch, G. and Ward, A.B. (1981), The Impact of Higher Oil Prices on Hill Country Farms in the Wairarapa. Department of Agricultural Economics and Farm Management, Massey University.

McChesney, I.G. (1979), Energy Use on Hill Country Sheep and Beef Farms Near Cheviot, North Canterbury. Occasional Paper No. 7, Joint Centre for Environmental Sciences, Lincoln College, Canterbury.

McChesney, I.G., Sharp, B.M.W. and Hayward, J.A. (1982), Energy in New Zealand Agriculture: Current Use and Future Trends. Energy in Agriculture, $1: 141-153$.

McLeod C.R. (1982), Ethanol from Beet: Economic and Management Aspects of Production. Paper presented to the Conference of the New Zealand Branch of the Australian Agricultural Economics Society, Picton, 1982 .

Muldoon, R.D., (1982) Financial Statement to the House of Representatives, 5 August 1982. 
New Zealand Department of Statistics. Agricultural Statistics 1979-80. Wellington, Department of Statistics.

New Zealand Meat and Wool Boards' Economic Service (1981), Annual Review of the Sheep and Beef Industry 1980/81. Publication No. 1845 , N.Z.M.W.B.E.S., Wellington.

New Zealand Ministry of Agriculture and Fisheries, Economics Division, 1982. New Zealand Fertiliser Statistics (1982),M.A.F. Media Services.

Partridge, E. (1977), A Note on the Importance of Petroleum Products as a Cost to the Australian Wheat and Grazing Industries and the Impact of Recent Price Increases. Quarterly Review of Agricultural Economics, Vol. 30, No. 4, Canberra.

Petrey, C. (1982), Fertiliser Demand. The Agricultural Economist 3: $29-31$.

Rich, M.M. and Zwart, A.C. (1979), Economic Factors Affecting Wheat Areas Within New Zealand. Discussion Paper No. 46. Agricultural Economics Research Unit, Lincoln College.

Robertson, B.T. and Rodgers, J.R. (1973), Predicting Fertiliser Demand. New Zealand Fertiliser Manufacturers' Research Association Fourteenth Technical Conference Proceedings, pp. 167-175.

Thompson, A.M.M. (1982), A Farm-level Model to Evaluate the Impacts of Current Energy Policy Options. Research Report No. 128, Agricultural Economics Research Unit, Lincoln College. 
A P P E N D I C E S 

Assumptions Used in the Formulation of Table 1 (Derived from Brown and Pearson, 1977; Johnson and Topp, 1981).

'Direct Energy Inputs' excludes any allowance for supply losses and excludes the negligible quantities of light Fuel Oil, Avgas, Blended Heating Oil, Coal and Gas used directly by farmers.

Motor Spirit/Diesel is derived from data on 'Deliveries to Agriculture and Hunting' which include Farming (sheep, beef, crop, dairy, poultry, tobacco, market gardening, orchardists, mixed general), Agricultural Contracting; Commercial Hunting and Trapping; Lime and Fertiliser Spreading; Shearing; Landscape Gardening; Bee Keeping and Honey Production; Livestock and Agricultural Services; Noxious Animal Control; and Game Propagation.

* Estimates have been made of the proportion of the total deliveries which represents sales to farmers. Prior to 1977 these estimates were made on an annual basis by A.E.R.U. staff after discussions with the major oil companies. Since that time it has been assumed that 82 per cent of gasoline deliveries and 80 per cent of light diesel has been sold to farmers.

* The energetic values used are:

$$
\begin{array}{ll}
\text { Premium Grade Gasoline } & -34.39 \mathrm{MJ} / 1 \text { itre } \\
\text { Regular Grade Gasoline } & -33.16 \mathrm{MJ} / 1 \text { itre } \\
\text { Light Diesel Oil } & -37.48 \mathrm{MJ} / 1 \text { itre }
\end{array}
$$

(Dawson, 1978)

Source: New Zealand Department of Statistics: Monthly Abstracts of Statistics: Deliveries of Petroleum Fuels by Industry.

Electricity - has been defined as 'the use of electrical energy for an agricultural, horticultural or stock raising type of activity... The figures in general will be exclusive of supply to farm houses unless there is only one service line or one meter on the property.'

* The energetic value used for electricity is $3.6 \mathrm{MJ} / \mathrm{kwh}$. (Dawson, 1978).

Sources: N.Z.E.D. Annual Statistics in Relation to Electric Development and Operation (Various issues) New Zealand Official Yearbook $1976-82$.

Indirect Energy Inputs: The energy intensity of the various forms of energy input has been assumed constant over the period, therefore changes in the energy productivities of manufacturing or extraction processes would not be reflected in Table 1 .

Fertiliser - includes fertiliser and dry lime.

* Because of the large amount of energy released in the conversion process of sulphur to sulphuric acid, fertiliser works in New Zealand have negligible additional energy requirement. The data in this table, therefore, only include the energy requirements of the raw material inputs up to the works gate. Deliveries only deviate slightly from quantities manufactured each year, the average fluctuation during 1970-76 being \pm 1.8 per cent. 
* Energetic values used 1 isted below.

\begin{tabular}{lc}
\hline $\begin{array}{c}\text { Type of } \\
\text { Material }\end{array}$ & $\begin{array}{c}\text { Energy } \\
\text { Requirement }\end{array}$ \\
Rock Phosphate & MJ/kg \\
Serpentine & 1.8 \\
Dry Lime & 0.4 \\
Sulphur & 2.1 \\
Ammonium Sulphate & 5.3 \\
Potassium Chloride & 15.0 \\
Dolomite & 5.1 \\
Urea & 0.1 \\
Other Secondary Mixtures & 34.0 \\
Imported: Urea & 4.0 \\
Ammonium nitrate & 35.0 \\
Ammonium sulphate & 25.3 \\
Other & 16.5 \\
\hline
\end{tabular}

Sources: NZ Department of Statistics. 1973. Imports 1970-71, Part A. NZ Ministry of Agriculture. NZ Fertiliser Statistics. (Various issues Appendix 6. Materials used by fertiliser works in the manufacture of fertilisers)

Limestone Energetic value used for 1 imestone $=0.1 \mathrm{MJ} / \mathrm{kg}$

Source: NZ Ministry of Agriculture and Fisheries: NZ Fertiliser Statistics 1981. Table 7 Total Limestone Production for Agriculture (less lime used in fertiliser mixtures Appendix 6).

Fertiliser/Lime Transport 1971-1976: average delivery distance $=108 \mathrm{~km}$ 1977-1981: average fertiliser delivery distance $=103 \mathrm{~km}$ 1977-1981: average lime delivery distance $=56 \mathrm{~km}$.

* Energetic values used are $1.8 \mathrm{MJ} /$ tonne for road transport and $0.7 \mathrm{MJ} /$ tonne for rail transport (Dawson 1978). A 50 per cent modal split between road and rail is assumed.

Source: NZ Fertiliser Statistics 1981. Appendix 2: Primary fertilisers and secondary mixtures delivered from fertiliser works.

Ground Contract Operations Forty per cent of fertiliser and 90 per cent of lime are applied by ground contract with average application rates of $250 \mathrm{~kg} / \mathrm{ha}$ and $2500 \mathrm{~kg} / \mathrm{ha}$ respectively. Energy requirements are $237 \mathrm{MJ} /$ tonne for fertiliser and $76 \mathrm{MJ} /$ tonne for lime (Dawson 1978).

Agricultural Aerial Operations: Fuel consumption estimated as follows: For solids, at 100 litres/hour plus 15 per cent non-revenue flying time; for liquids at 90 litres/hour plus 25 per cent non-revenue flying time; for all other work at 80 litres/hour plus 25 per cent non-revenue flying time. Aviation fuel has an energetic value of 33.82 MJ/litre.

(Dawson, 1978 and AERU estimates).

Source: NZ Department of Statistics. Transport Statistics (various issues). Agricultural Aerial Work. 
New Tractors Energetic value of $165 \mathrm{MJ} / \mathrm{kg}$ and an average weight of $2000 \mathrm{~kg}$. Energy requirement per tractor has been assumed to be $3.3 \mathrm{x}$ $10^{5} \mathrm{MJ} /$ tractor. (Dawson, 1978).

Other Machinery The energetic value of all other new farm machinery was estimated by Brown and Pearson (1977) as $2100 \mathrm{TJ} /$ year. The stock of machinery has not altered greatly during the period since 1977 and the same estimate has been used throughout.

Fencing Posts Energy requirements for wooden, concrete and steel fence posts are 9.1 MJ/post, $76.2 \mathrm{MJ} /$ post and $145 \mathrm{MJ} /$ post. (Dawson, 1978).

Other Machinery The energetic value of all other new farm machinery was estimated by Brown and Pearson (1977) as $2100 \mathrm{TJ} /$ year. The stock of machinery has not altered greatly during the period since 1977 and the same estimate has been used throughout.

Fencing Posts Energy requirements for wooden, concrete and steel fence posts are 9.1 MJ/post, $76.2 \mathrm{MJ} /$ post and $145 \mathrm{MJ} /$ post. (Dawson, 1978).

Wire Energy requirements of $34 \mathrm{MJ} / \mathrm{kg}$ for $12 \frac{1}{2} \mathrm{H} . \mathrm{T}$. and of $38.0 \mathrm{MJ} / \mathrm{kg}$ for al1 other wire. (Dawson, 1978).

Drench and Dip From market estimates, the volume of drench consumed by agriculture for 1976 is taken at $1.7 \mathrm{~m}$ 1itres. Analysis of the proportion of active ingredient of each of the major products in this market indicates a weighted average composition of 7 per cent, or a total amount of active ingredient of $119,000 \mathrm{~kg}$. An additional 10 per cent allowance has been made for the dip market. It has been assumed that volume of drench and dip has not changed during the period.

* Energetic value of $136 \mathrm{MJ} / \mathrm{kg}$ has been assumed. (Dawson, 1978).

Pesticides etc. Energetic value of $136 \mathrm{MJ} / \mathrm{kg}$

Sources: NZ Department of Statistics, Industrial Production (various issues 1971-73). Part of Industry 389, 'Chemical Products n.e.i.', subsequently market estimates have been used.

Commercial Transport Expenditure on railage and cartage from NZ Department of Statistics, 1976 and 1980. New Zealand Official Yearbook 1976 p. 372 and 1980 p. 364 .

* Ninety per cent of total expenditure assumed attributable to road transport (Ambler, 1975).

* Proportion of total revenue in commercial rural road transport attributable to fuel expenses estimated from: NZ Ministry of Transport. Statistics of the Licensed Road Transport Industry 1973, 1976 and 1977.

* Analysis assumes 50 per cent of fuel used is diesel, 50 per cent petrol, with an energy requirement of $37.48 \mathrm{MJ} / 1$ and $34.39 \mathrm{MJ} / 1$ for diesel and petrol respectively. 



\section{APPENDIX 2}

Fertiliser and Fuel Subsidies, Rebates and Prices

\section{A 2.1 Fertiliser Subsidies 1971-1981}

\begin{tabular}{|c|c|c|c|}
\hline Year & Price & $\begin{array}{c}\text { Transport } \\
\text { (as from } 1.8 .69)\end{array}$ & Spreading \\
\hline $7 / 70$ & $\$ 5.00 /$ ton & $\begin{aligned}<20 \text { miles } & =9 \mathrm{c} / \text { ton } / \mathrm{mile} \\
20-100 \mathrm{miles} & =5 \mathrm{c} / \text { ton } / \mathrm{mile} \\
>100 \mathrm{miles} & =2 \mathrm{c} / \text { ton } / \mathrm{mile}\end{aligned}$ & \\
\hline $6 / 71$ & $\$ 7.50 /$ ton & $\begin{aligned}<20 \text { miles } & =9 \mathrm{c} / \text { ton } / \text { mile } \\
20-100 \text { miles } & =7 \mathrm{c} / \text { ton } / \text { mile } \\
>100 \text { miles } & =4 \mathrm{c} / \text { ton } / \text { mile }\end{aligned}$ & $\$ 1.00 /$ tonne - aerial spread \\
\hline $6 / 73$ & $\begin{array}{l}\$ 7.50 / \text { ton } \\
\text { for first } 30 \\
\text { tons only }\end{array}$ & $\begin{aligned}<20 \text { miles } & =7 \mathrm{c} / \text { ton } / \mathrm{mile} \\
20-100 \mathrm{miles} & =6 \mathrm{c} / \mathrm{ton} / \mathrm{mile} \\
>100 \mathrm{miles} & =4 \mathrm{c} / \mathrm{ton} / \mathrm{mile}\end{aligned}$ & \\
\hline $7 / 74$ & $\$ 18.25 /$ ton & & \\
\hline $7 / 75$ & $\$ 28.47 /$ ton & & $\begin{array}{l}\$ 4.50 / \text { ton - ground contract } \\
\$ 3.00 / \text { ton - farmer spread } \\
\$ 7.50 / \text { ton - aerial spread }\end{array}$ \\
\hline $7 / 76$ & $\$ 25.00 /$ ton & $\downarrow$ & $\begin{array}{l}\$ 4.00 / \text { ton - ground contract } \\
\$ 2.50 / \text { ton - farmer spread } \\
\$ 8.50 / \text { ton - aerial spread }\end{array}$ \\
\hline $7 / 77$ & $\$ 22.50$ tonne & $\begin{aligned}<65 \mathrm{~km} & =4.4 \mathrm{c} / \text { tonne } / \mathrm{km} \\
65-250 \mathrm{~km} & =2.7 \mathrm{c} / \text { tonne } / \mathrm{km} \\
>250 \mathrm{~km} & =2.0 \mathrm{c} / \text { tonne } / \mathrm{km}\end{aligned}$ & \\
\hline $7 / 78$ & $\$ 32.00 /$ tonne & $\begin{aligned}<65 \mathrm{~km} & =8.0 \mathrm{c} / \text { tonne } / \mathrm{km} \\
65-250 \mathrm{~km} & =5.0 \mathrm{c} / \text { tonne } / \mathrm{km} \\
>250 \mathrm{~km} & =3.0 \mathrm{c} / \text { tonne } / \mathrm{km}\end{aligned}$ & $\begin{array}{l}\text { Spreading bounties off } \\
\text { except aerial bounty of } \\
\text { \$2/tonne }\end{array}$ \\
\hline $7 / 79$ & $\$ 15.00 /$ tonne & & \\
\hline $7 / 82$ & $\downarrow$ & $\begin{aligned}<40 \mathrm{~km} & =6.0 \mathrm{c} / \text { tonne } / \mathrm{km} \\
40-250 \mathrm{~km} & =7.0 \mathrm{c} / \text { tonne } / \mathrm{km} \\
>250 \mathrm{~km} & =8.0 \mathrm{c} / \text { tonne } / \mathrm{km}\end{aligned}$ & $\nabla$ \\
\hline
\end{tabular}




\section{A 2. 2 Fertiliser, Fuel and All Farming Cost Price Indices}

Although the weighted net fuel price index rose more sharply than the index of all other farm costs after the first oil shock in 1973, it slowed in 1978 and 1979 and thereafter rose very steeply. The price of fertiliser and lime to the farmer, however, did not increase much more rapidly than other farm costs until 1979-80 when the price subsidy was reduced substantially and the manufactured cost of superphosphate escalated. 
FIGURE A2.2

Fertiliser and Lime, Weighted Net Fuel, and all Farming Cost

Price Indices 1972-81

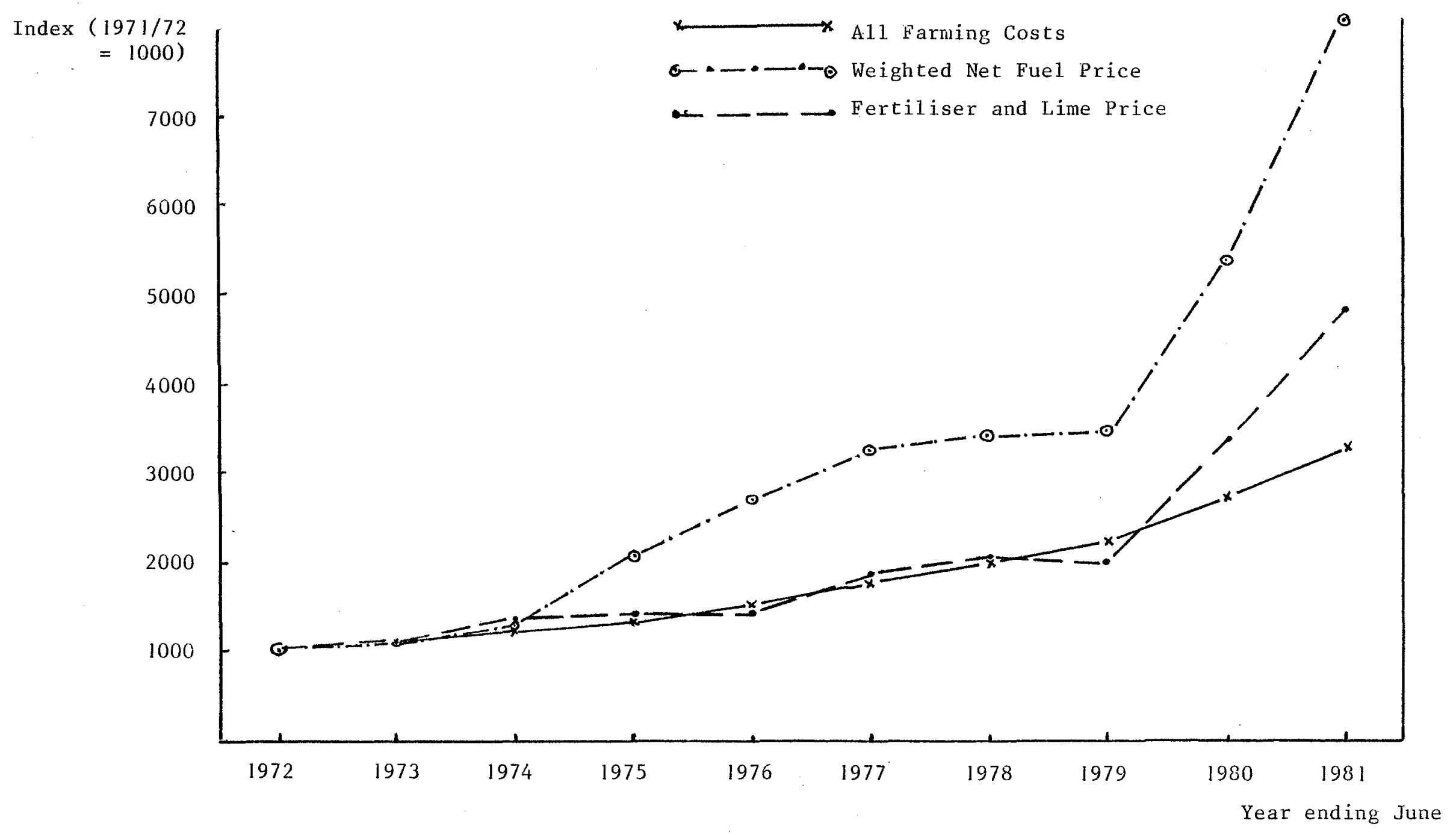


36.

\section{A 2.3 Fertiliser Price Indices}

The fertiliser price index used in the analysis includes the price of lime and of spreading but not of transport. A weighted index of the applied cost of fertiliser was not available but indices of the subsidised and unsubsidised costs of superphosphate are graphed in Figure A 2.2. It can be seen that the subsidised superphosphate price index and the fertiliser and lime price index are closely related from 1976 on but are divergent in 1974 and 1975.

The rate of increase in the subsidised superphosphate price exceeds that of the unsubsidised price from 1979 forward as the subsidy comprises an increasingly small proportion of the value of fertiliser. 
FIGURE A2.3

Fertiliser and Lime, Subsidised Applied Cost of Superphosphate and Unsubsidised Applied Costs of Superphosphate Price Indices 1972-81

$\longrightarrow$ Subsidised Applied Cost of Superphosphate $\leftarrow-\cdots \rightarrow$ fertiliser and Lime

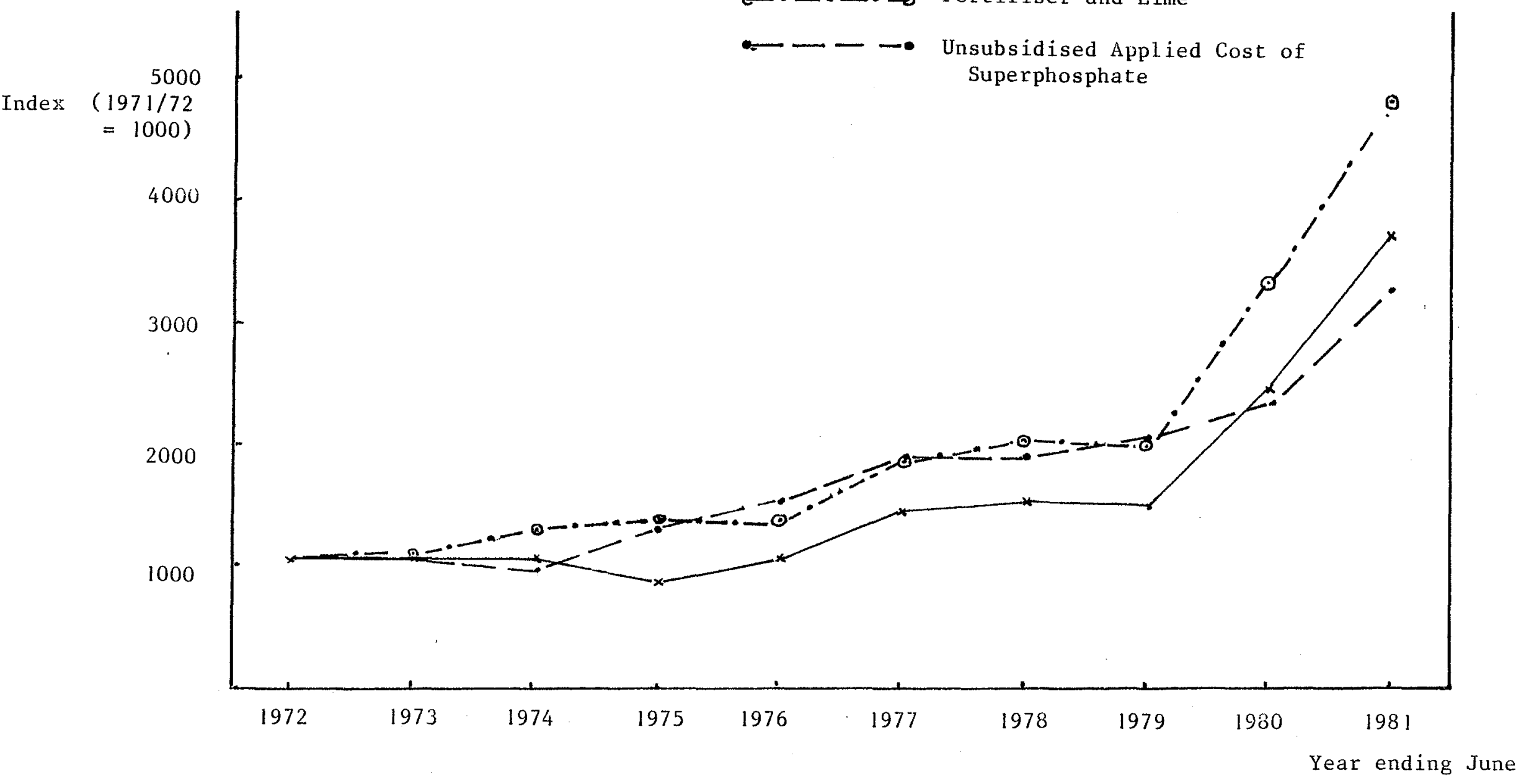


(\$/tonne)

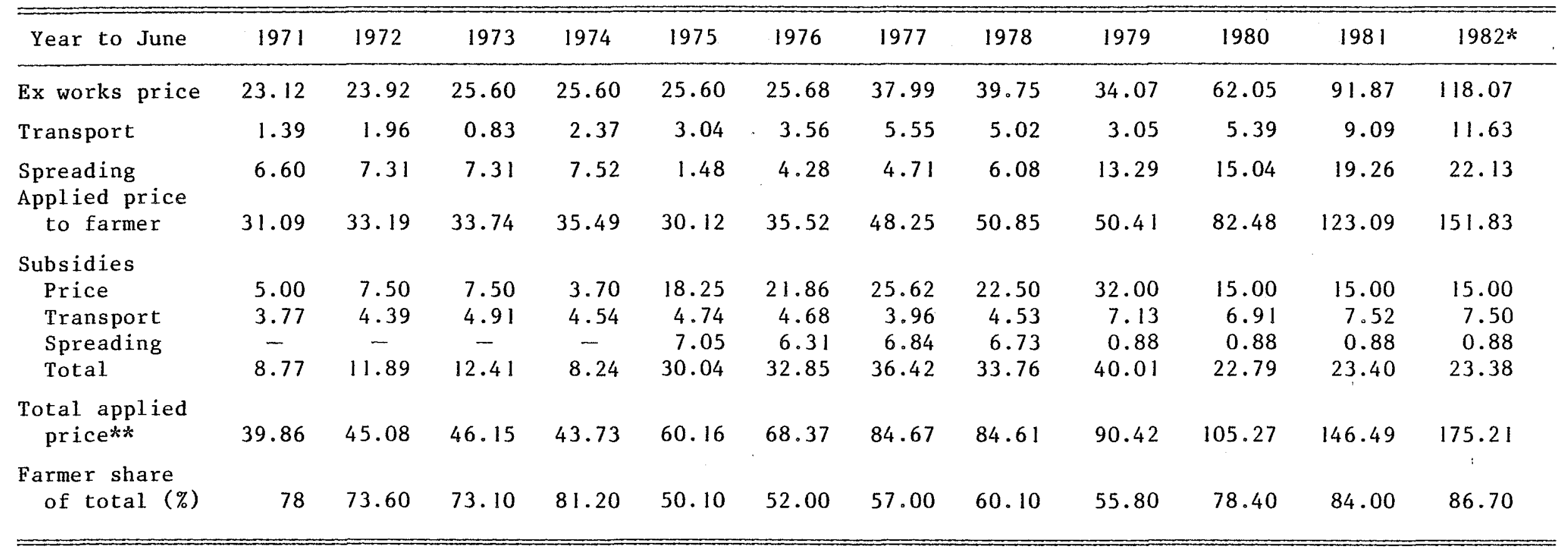

* Estimate

** Total applied price is the resource price from the national viewpoint

Source: Petrey (1982) The Agricultural Economist 3:30. 


\section{A 2.5 Motor Spirits Duty and Duty Rebates}

Until the introduction of the Road User Tax on 1 April 1978, two vehicle categories were exempt from motor spirits duty. These were:

Class A - Vehicles used off the public highway

Class B - Vehicles used on the public highway but only in 'gate to gate' transportation.

The introduction of the Road User Tax led to the exemption of a third category of vehicles including those vehicles exceeding 3.5 tonnes, used in road transportation who became subject to the separate Road User Tax.

Vehicles in this category became exempt from all of that part of the petrol tax destined for the National Roads Board Account, but did not receive as high a rebate of the Consolidated Accounts tax as did Class A and Class $B$ vehicles.

From June 1978 the motor spirits was 12.7 cents/1itre; Class A and Class $B$ exempt users were eligible for a rebate of 11.7 cents/1itre while those subject to Road User Tax were eligible for 9.7 cents/litre rebate. In July 1982 the motor spirits levy was restructured to include:

(a) A tax of 15 per cent of pre-tax wholesale value, aimed at encouraging efficient use of imported fuel and to provide a reasonable measure of protection for domestic alternative fuels, was levied on all motor spirits.

(b) A general revenue tax of 5 per cent of pre-tax wholesale value on petrol.

(c) National Roads Board Tax.

\section{A 2.6 Weighted Net Fuel Price Index 1972-1981}

$\begin{array}{ll}1971-72 & 1000 \\ 1972-73 & 1038 \\ 1973-74 & 1283 \\ 1974-75 & 2075 \\ 1975-76 & 2660 \\ 1976-77 & 3245 \\ 1977-78 & 3472 \\ 1978-79 & 3547 \\ 1979-80 & 5340 \\ 1980-81 & 8038\end{array}$

\section{A 2.7 Rate of Motor Spirits Duty}

Date

26 February 1975

23 May 1975

1 April 1977

2 June 1978

5 August 1982

1 October 1982
Duty

4.0 cents/1itre

8.7 cents/1itre

9.7 cents/1itre

12.7 cents/1itre

15.8 cents/1itre

16.2 cents/1itre 
40.

\begin{tabular}{|c|c|c|}
\hline \multicolumn{2}{|c|}{$\begin{array}{ll}\text { February } & 1975 \\
\text { November } & 1978\end{array}$} & Local authority tax on petrol \\
\hline
\end{tabular}

A 2.8 Rate of Motor Spirits Duty Refund

$\begin{array}{rrr} & \text { Class A\& B } & \text { Road User Tax } \\ 5 \text { May 1967 } & 3.98 & \\ 1 \text { Apri1 1974 } & 4.00 & \\ 23 \text { May 1975 } & 8.77 & \\ \text { I Apri1 1977 } & 9.70 & \\ 2 \text { June 1978 } & 11.70 & 9.70 \\ 5 \text { August 1982 } & 8.50 & 8.50 \\ \text { 1 October 1982 } & 8.90 & 8.90\end{array}$




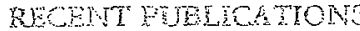

\section{EESEARCE REORTS}

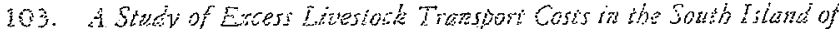

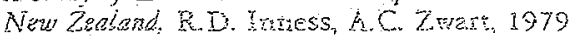

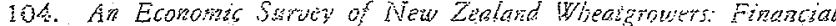

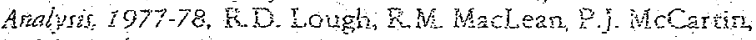
Mi. Rich 1979

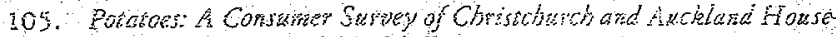

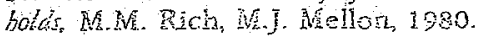

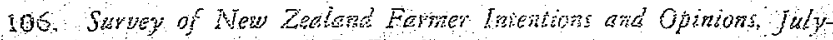

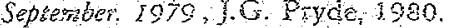

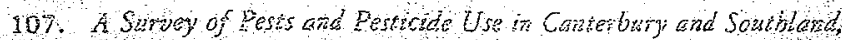
J. B. Munirord, 1980

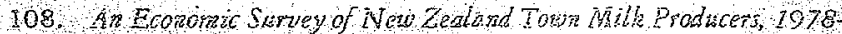
79, RG. Morfet 1980

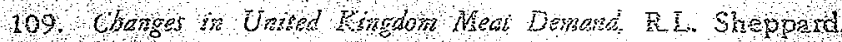
1980

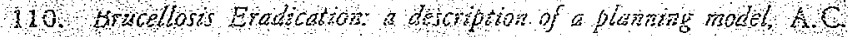
Beck, 1980

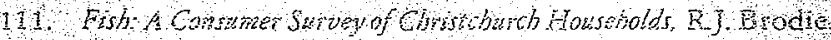
1980 .

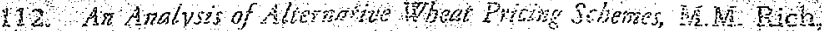
L.) Poulds, 1980 .

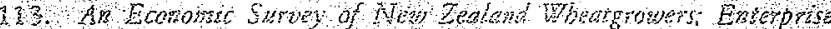

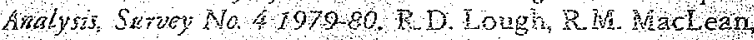
P. MCCarcin N M Phh, 1990

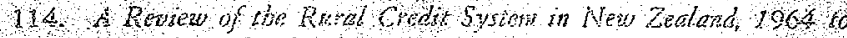
1970, JG, Prge, SWAm, 980

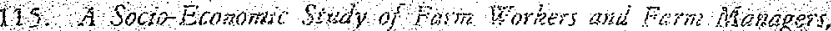
G. I Haris, 1980

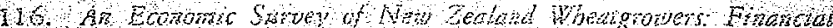

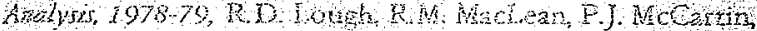
Matile 1980

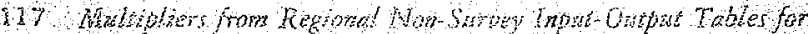

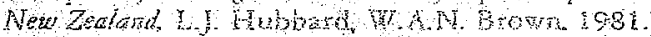

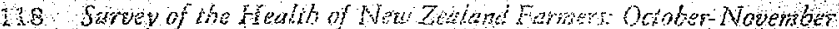
1980, JC. pride 198

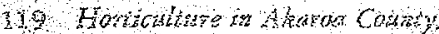
R) Shepard ish

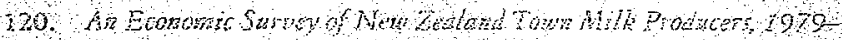

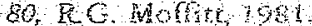

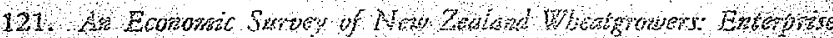

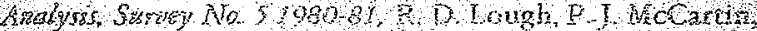
Now $1, n, 198$

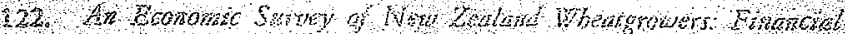

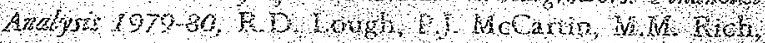
108

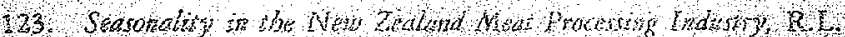
Sheopard, 1982

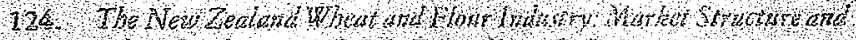

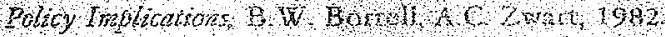

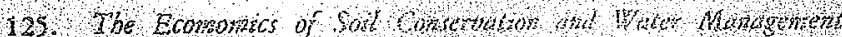

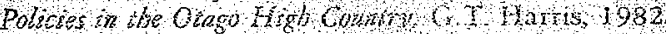

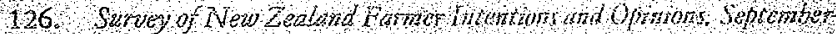

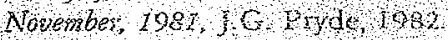

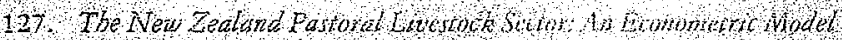

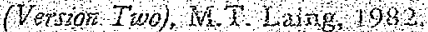

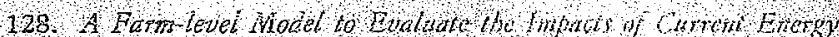
Polay Ofizons, d W M Thonson 1098

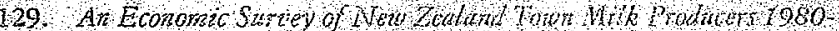
$81, \mathrm{R}, \mathrm{G}$ Moftet 1902

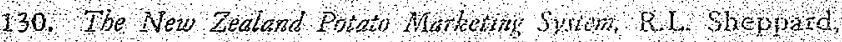
1982.

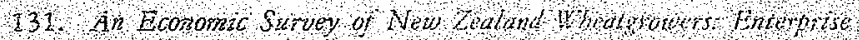

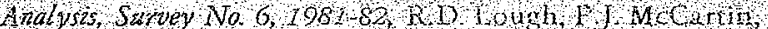
1.1. $\mathrm{RH} 1,1982$

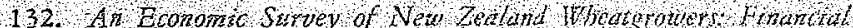

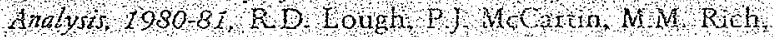
1982

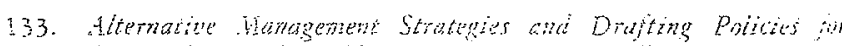

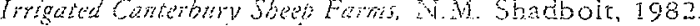

134. Econoratio of the Sheep Dreeding Operations of the Depariment th Lana's unt Surey, A. T.G. IHCAthia, 1933

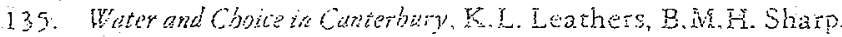
W. A. Y. Brown, 1983

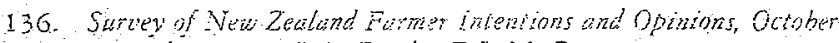
December, 1982, J.G. Pryda, E.J. McCartin, I983.

DISCUSSION PAPFRS

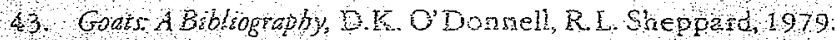

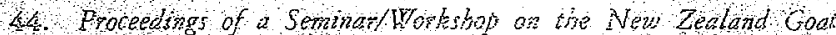

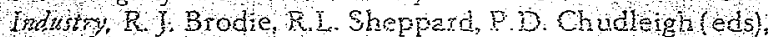
1979

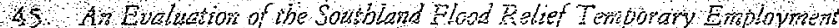

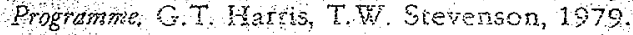

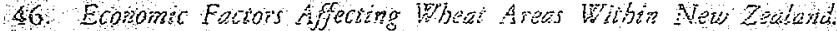
W.W RiCh, A.C ZWarE, 1979.

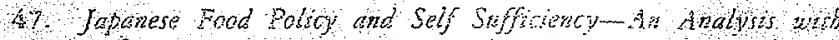

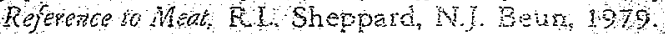

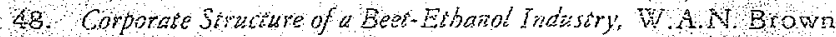
B. Dent, 1980

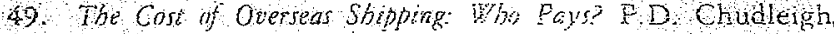
1980 .

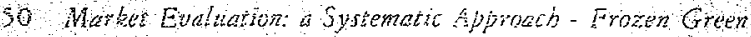
Sprouting Butcolit i Sheppara, i9go.

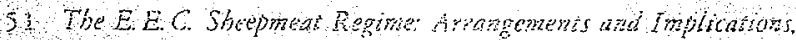
N. Blyh, 1980

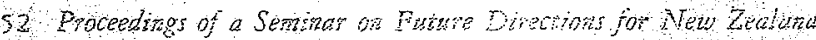
Lañdharkag edted

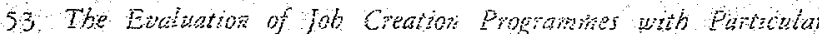

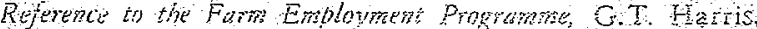
1981 .

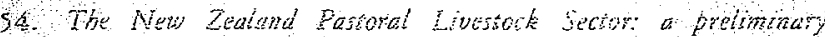
ecominetrit model, î.T. Laing, A. C. Zwart, 1981

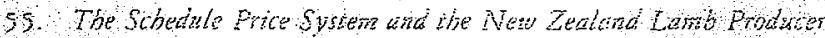
N M. Shadbolt 1981

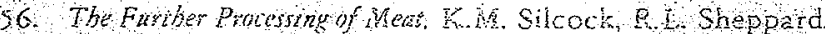
1981 .

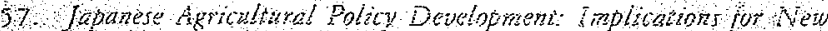
Zuatand, A Znare, 198 .

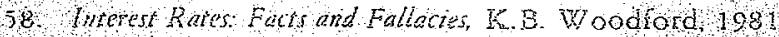

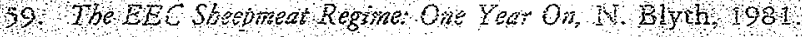

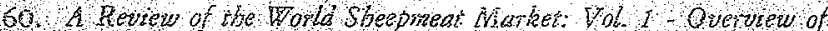

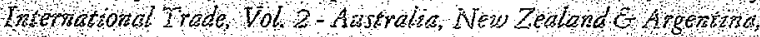

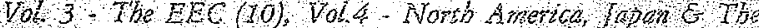

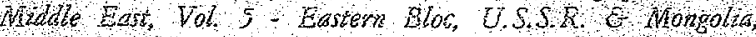
N. Sych, $19 \% 1$

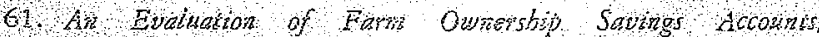
16. Woodrord, 1981 :

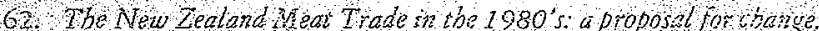
B. Ross, F. L. Sheppard, A.C. Zmant 1982

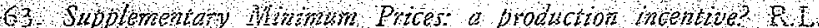
Sheppat,, $\mathrm{Mr}$ Bgs, 1982

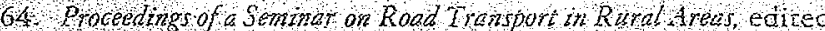
br P D Chudaigh, A, NAlolson, 1982

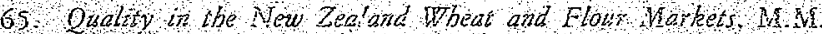
$01 \mathrm{Mg2}$

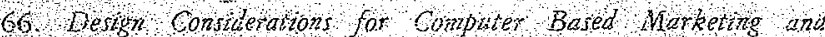
Whortictom Systoms, PU Nuthall, 1982

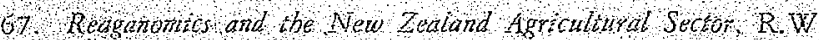
B.hall, 1983.

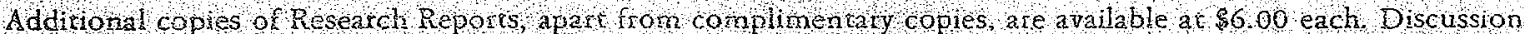

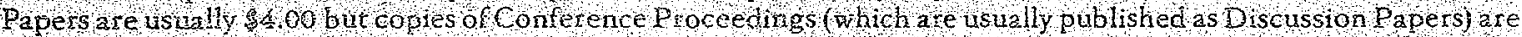

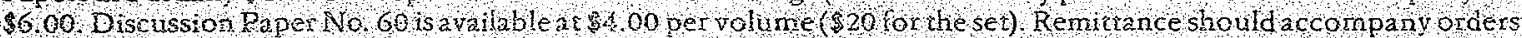
addressed to. Bookshop, Lheoln College, Canterbury, Wew Zealand. Please ado $\$ 0.90$ per copy lo cover postage. 